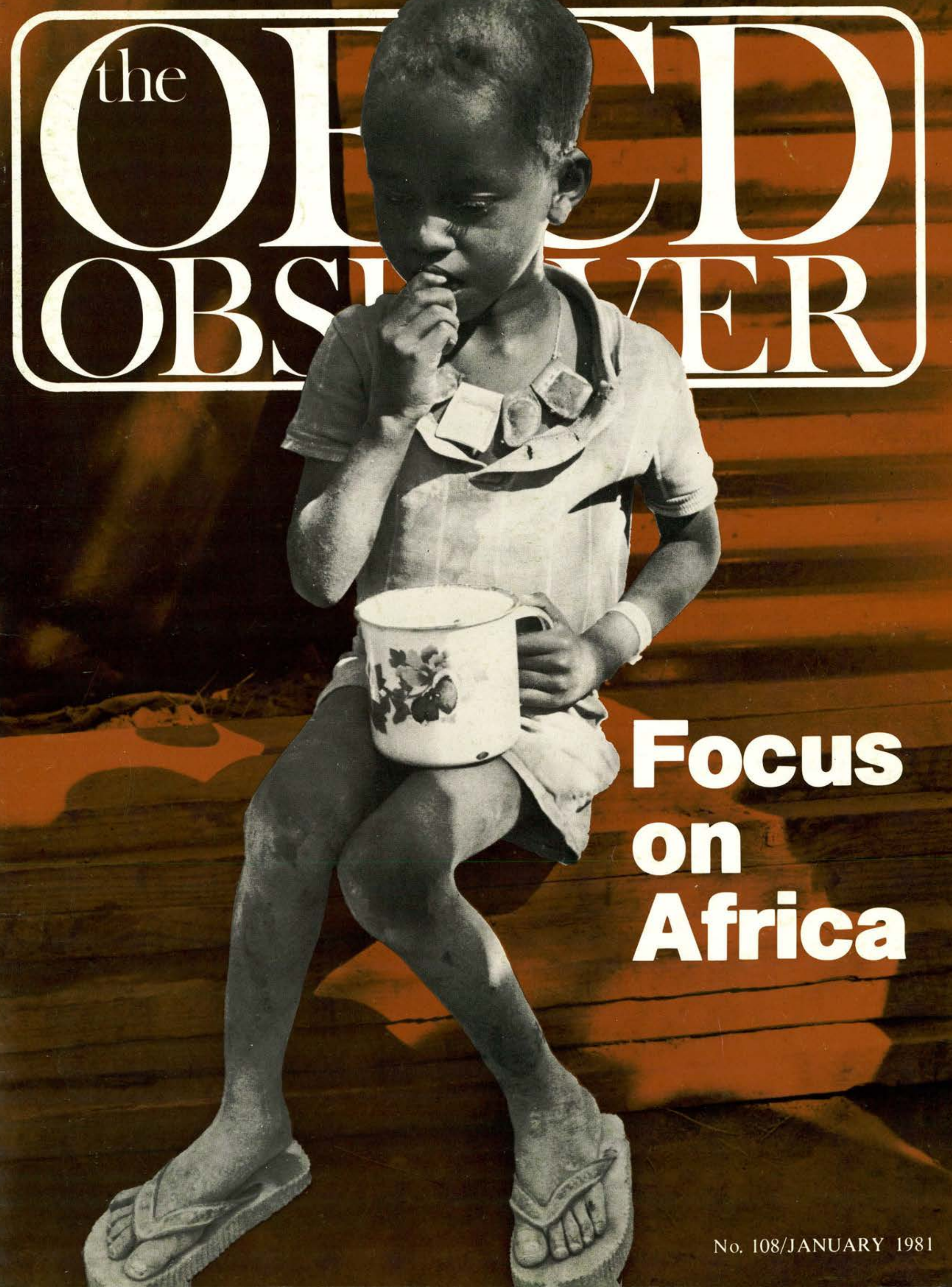




\section{Contents}

TWENTIETH ANNIVERSARY OF OECD

3

THE FIRST SCORE

by John Fay, Director for Publications Policy, OECD

CAN THE RICH COUNTRIES ADAPT? NEEDS AND DIFFICULTIES

by Assar Lindbeck, Professor of International Economics

of the Institute for International Economic Studies, Stockholm

PROSPECTS FOR RECOVERY

Highlights from OECD Economic Outlook - December 1980

IEA MINISTERS TIGHTEN UP ON OIL

EXPERTS' RECOMMENDATIONS ON COAL

SITING OF NUCLEAR PLANTS

FOCUS ON AFRICA

\section{(O) ECD}

No. 108

January 1981

PUBLISHED bi-monthly in English and French by THE ORGANISATION FOR ECONOMIC CO-OPERATION AND DEVELOPMENT

\section{EDITORIAL OFFICES}

OECD Information Service, Château de la Muette, 2, rue André-Pascal, F 75775 PARIS, CEDEX 16.

Individual articles not copyrighted may be reprinted providing the credit line reads "Reprinted from the OECD Observer" plus date of issue, and two voucher copies are sent to the Editor. Signed articles reprinted must bear author's name.

The Organisation cannot be responsible for returning unsolicited manuscripts.

Signed articles express the opinions of the authors and do not necessarily represent the opinion of OECD

Annual Subscription Rates: $£ 4.00$, US $\$ 9.00, F 36.00$.

Single copies: $£ 0.80$, US\$1.75, F7.00.

EDITOR: Jane Bussière

ASSOCIATE EDITOR:

Ulla Ranhall-Jeanneney

ART, PRODUCTION AND LAyOUt:

Marc Delemme

ASSISTANT:

Gérald Tingaud

PHOTO RESEARCH:

Silvia Lépot

Rina Maiden

All correspondence should be addressed to the Editor.

PHOTOS: Cover: Arild Vollan - Unicef; page 3: Alain Dejean - Sygma; page 7: James Andanson - Sygma; page 8: Bundesbildstelle, Bonn; page 9: Central Office of Information, London; pages 14-15: J.P. LaffontSygma; page 17: Alain Noguès - Sygma; page 19: Henri Pribik - CCE; pages 20-21: Bundesbildstelle, Bonn; page 22: $H$. Dalrymple Unicef; page 23 (top): CEA, France; (bottom): F. Mattioli-FAO; page 25 (top to bottom, left to right): Ethiopia Office - Unicef; R. Seitz WHO; United Nations; Horst Cerni - Unicef; page 26: Almary - Vauthey - Unesco; page 27: B. Campbell - Unicef; page 28: ILO. 


\section{0th Anniversary of OECD}

The President of the French Republic, Valéry Giscard d'Estaing, visited the OECD on 15th December, for the celebration of the 20th anniversary of the signing of the OECD Convention.

The French President addressed a special session of the OECD Council, as did the Danish Foreign Minister, Kjeld Olesen - Denmark currently presides over the Ministerial Council - and OECD's Secretary-General, Emile van Lennep.

"We know that the synchronisation of countries' economic situations is the distinguishing feature of world crises. The present crisis is the most serious,

the longest-lasting and the most trying that the world has known since the Thirties.

None of our nations can hope to pull itself out of the crisis in isolation, for the causes are common to all. But each through its own efforts

can help to solve the problem we all share.

A return to isolationism would be a mistake. That is clearly realised in the OECD, which has successfully devoted itself to the development of trade. But in times of crisis isolationism can be skilfully disguised. Trying to export one's

unemployment, trying to transfer it to one's partners is a free-tradist form of isolationism."

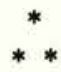

"The countries represented in the OECD are only one of the groups which must show active solidarity with the Third World. At the moment they provide three-quarters of worldwide official development assistance, namely \$22 billion,

in 1979. This apportionment does not reflect the respective aid-giving capacities in the world. All countries must face up to their responsibilities in this regard and each must contribute its fair share, including the East European countries and those whose natural resources have recently been turned to profitable account."

Valéry Giscard d'Estaing President of the French Republic

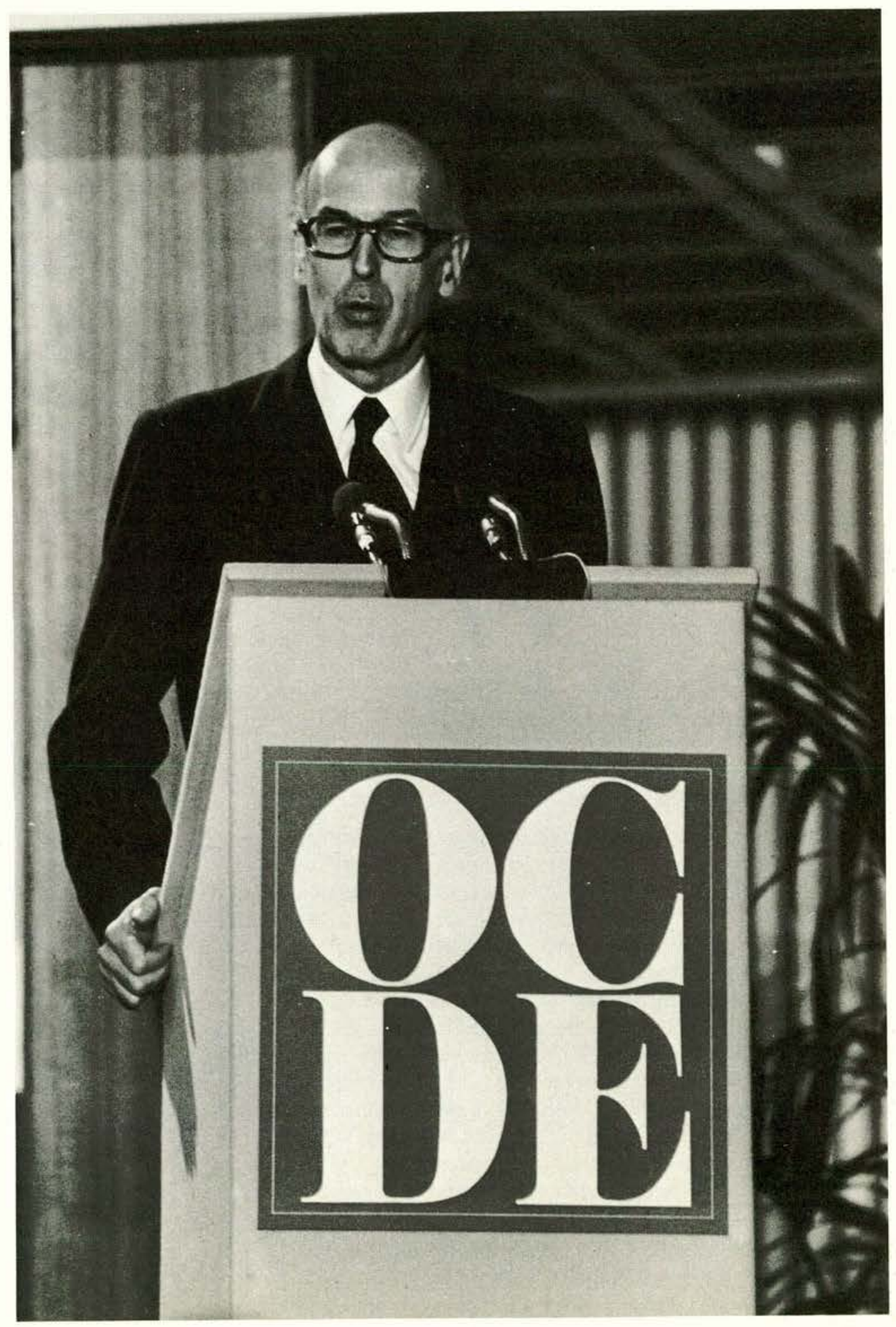




\title{
The First Score
}

\author{
by John Fay, \\ Director for Publications Policy, OECD
}

A $\mathrm{n}$ institution celebrating its 20 th birthday does better to worry about the future than to feast on - or grieve over the past. But it can be instructive to examine how far the problems of today differ from those of twenty years ago - and why.

Twenty years ago there was worry, obviously, about the dangers of economic fission between the newly-formed Common Market, the rest of Europe, and North America. There was also vague worry about energy - but with no expectation that the crunch was only a decade away. Conventional energy resources, said a contemporary OECD report, could satisfy world needs for the moment. Nuclear energy would become a major necessity, but only "perhaps in a few decades".

OECD's major general worry was about growth - the primary unsecured objective. Apart from anything else, it was imperative if surplus farm workers were to be transferred to other sectors. Was there scope for growth in Europe of anything like the $4 \frac{1}{2}$ percent rate of the Fifties? Could the United States get out of the stagnation into which it seemed to have fallen?

OECD set up a 50 percent growth target for the Sixties, but with considerable doubts. There seemed plenty of physical scope : the manpower supply was on tap, and the investment needs seemed not unrealistic. But there were doubts whether demand management would prove adequate, and there seemed some danger of unnecessarily restrictive attitudes towards public deficit financing. Clearly, an important change was required in the United States.

More in tune with today's thinking was the warning that expansive demand management, although necessary, was not a sufficient condition of growth : it was essential, particularly in Europe, to forestall continuous price increases that might call for protracted demand restraint. But the terms in which the problem was expressed show, eloquently enough, the difference between yesterday and today. It was not a question of how to defeat inflation so as to put the growth aim back on a pedestal from which it had fallen. Rather, the problem was to find policies that would spare governments the need to reduce the priority accorded to growth. What was the optimum combination, to this end, of selective demand management, active labour market policies to ease the problem on the supply side, and incomes policies? Apart from encouraging real capital accumulation, to what extent should government assume new responsibilities for education and research, on the grounds that these were major factors in the growth process?

Admittedly, the danger of balance-of-payments constraints
- the legacy of the Fifties and the precursor of the Seventies loomed large. Their effects might be asymmetrical between strong countries and weak, with a depressive bias. It might be difficult, in countries such as the United Kingdom and the United States where productivity growth was relatively slow, to keep the increase of money incomes lower than in the countries where productivity was growing relatively fast - France, Germany and Italy. And the unequal development of national capital markets could serve as an additional disequilibrating factor in the fixed exchange rate world.

But for the greater part, the worries of twenty years ago were worries about individual countries. There was need for Britain to emerge from its successive times of trouble, which superficially manifested themselves as balance-of-payments problems and led to go-stop policy cycles with repeated setbacks to growth. There seemed to be a problem of excessive saving in Germany, perhaps emanating from an exchange rate that was set too low immediately after the war. (In the Bretton Woods system, a low exchange rate for a single country was a dynamic form of protection, providing home producers with an initial competitive advantage which, because it wasn't guaranteed, they were careful not to lose.) There was, for some years, lingering doubt whether France could consolidate the stabilisation it had achieved in the late Fifties, escaping from the cycle of inflation, protection and various forms of devaluation, and re-building an industrialised market economy.

Above all, the question mark seemed to hang over the United States - responsible then for about 55 percent of the output of the OECD world, as against only 35 percent today. Both growth and the price increase had, for years, been hovering around 1 percent a year. The burning question seemed simply whether American growth could be raised, with no great fear that this might lead to a loss of internal or external balance. Indeed, since the weakening of the dollar seemed primarily due to outward capital flows, there was some expectation that faster growth would actually strengthen the currency. In the event, developments in America proved both better and worse than feared. Exemplary demand management produced growth with price stability for some years but then gave way to policies which accommodated inflation. As the latter took hold in the later Sixties and the dollar came increasingly under attack, the industrialised world lost the linchpin that had held the pricelevel in check, and recognised the fact.

Today, the major economic problems that OECD governments perceive are of a fundamental, across-the-board, nature rather than country-specific. Such general worries as there were in the 1960s have been joined by a host of others. Discussion in 
OECD has shifted somewhat - away from what individual governments are doing today and towards what they might or might not do, in common, over a period of years and the likely nature of the results. There is a broad consensus on what the immediate priorities have to be, and a reasonable acceptance of the path that each government is treading. But there is a fundamental uncertainty - untypical of the Sixties - about how people behave in making their economic decisions and why.

Clearly, OECD economies are currently faced with large changes - in personal tastes and attitudes to work; in corporate attitudes towards risk, because of inflation; in relative prices, because of energy; in the international division of labour, partly because of the newly industrialised countries (the NICs); and in productivity trends, partly because of structural changes in output and the labour force. Perhaps these changes are so vast that the nature of the game, and the rules by which it has to be played, are now totally different from the early Sixties. Perhaps the world never did work according to the views so widely accepted then. The optimist, perhaps, would still follow the McCracken Group which suggested to OECD, in 1977, that the recent unpleasantness in the rich man's club reflected a fortuitous combination of accidents and mistakes, and didn't necessarily herald a new and more difficult economic era. These are typical of the uncertainties on which governments, in the early 1980s, want to consult each other in OECD, seeking to establish a workable doctrine on which policies can be based.

In one very fundamental sense, today's economic scene is marked by the outcome of events which were already taking place when OECD was born - the movement towards almost total interdependence of national economies, whether rich or poor. Interdependence grew in the late Fifties as, progressively, trade liberalisation was followed by currency convertibility and greater freedom for international capital. Today, with the expansion of the multinational enterprises, the abandonment of fixed exchange rates and the growth of international bank credit and the Euro-currency markets, the scope for national isolation from changing world fortunes is singularly limited. To these factors can be added the ever-increasing international demonstration effects on private behaviour, with people being influenced more and more by what goes on beyond their borders as communications are beamed through space. And a falling role for the dollar as a key currency, and the growth of a multi-currency reserve system, will intensify this interdependence. OECD has to try to make interdependence work for world prosperity, and forestall tendencies to revert to narrow national or regional arrangements with their inescapable depressive effects.

But there are senses in which today's problems seem profoundly different from those of twenty years back. Bargaining for income shares has become clearly more aggressive inside nations, with the loss of the money-illusion which once made bargainers think in terms of nominal incomes rather than the goods that such incomes could buy, and with the growing habit of arguing about after-tax rather than pre-tax income. It has also become more aggressive between nations, which is one of the reasons why the energy crunch came sooner than expected. At the same time, growth has become more difficult and expensive to achieve, partly because environmental constraints and preferences have changed, with an understandable desire simultaneously to increase output and reduce the nuisances that the production process creates. The need for OECD markets to accommodate the products of the newly-industrialised countries (the NICs) as they develop export-oriented industries in the wake of financial transfers and expertise from the North has increased. This is one reason why, as Professor Lindbeck argues in a later article, the need for OECD economies to adapt their production structures has become, simultaneously, more pressing and more difficult. And a major problem, distinguishing the Eignties from the Sixties, is that the first flush of enthusiasm for helping the less-developed countries has weakened. If it proves impossible (and it is currently proving increasingly hard) to ensure financial flows from OECD and OPEC countries which are adequate to enable the poorer countries to achieve a reasonable rate of development, international relationships risk unprofitable strain.

OECD countries know where they want to go, but there is still legitimate scope for debate about the policies most likely to take them there.

- The thorniest problem of all concerns, probably, the appropriate combination of demand and supply policies. Lax demand policies can jeopardise such progress as has so far been made towards lower inflationary expectations. But continuous strong restraint entails its own dangers. How can policy prevent investment, inventiveness and productivity falling faster than aspirations, with the risk of greater rather than lower inflationary pressure?

- To what extent is there scope for consensus-type discussion, on a continuing basis, between governments and the social partners? Can this influence price and income determination and attitudes towards technological changes and, more generally, build bridges over the disparate attitudes of labour, management and the public authorities? In this perennial debate, the OECD Observer has already suggested that off-again on-again agreements are probably more disturbing than rewarding. But more lasting consensus arrangements could be a different matter, so long as they worked for the ultimate benefit of the consumer and not at his expense.

- How can labour-market and social policies best be harnessed to support traditional macro-economic policies, so as to make the inevitable period of very modest growth a supportable and constructive interlude? Clearly, public expenditure has to be so designed as to support future productivity growth. At the same time, there is the immediate need for public expenditure to temper the effects of unemployment, which fall particularly on women and the young, on ethnic minorities and on immigrants. Such expenditure is increasingly necessary - but increasingly difficult to finance.

- Particularly thorny, too, is the question of how to restrain protectionist action when its superficial attractions are growing fast. Twenty years ago, wisdom secured that the almost simultaneous formation of the Common Market and the European Free Trade Association did not lead to self-contained trade areas. But that was in a more expansionary climate, and in today's conditions it has to be asked, all over again, whether the industrialised world is going to be wise enough to preserve free trade - both inside itself and with the less-industrialised countries. Is it going to be able to minimise the approach to "internationally managed trade" but, simultaneously, to prevent purely nationalist forces competing to erect trade barriers unilaterally?

The scope for complacency, in the face of these problems, is zero. But at least there remains widespread - probably increasing - recognition that they are problems which have to be solved internationally. And some confidence can, perhaps, be gained from recent experience. In 1960, many might have feared that industrial democracy could not survive the sort of experience depicted by the latest OECD Economic Outlook, summarised elsewhere in this issue, with inflation clinging obdurately to the double-digit rate and unemployment rising inexorably towards the 25 million mark. The managed market economies have, in fact, proved remarkably resilient in the face of trouble. OECD's task is to confirm this resilience, and this will probably best be done by accentuating the market rather than the management. 


\title{
Can the Rich \\ Countries Adapt?
}

\section{Needs and Difficulties}

\author{
by Assar Lindbeck
}

\begin{abstract}
With a "manifest crisis" in steel formally declared in the European Community and acute difficulties facing many of the major industries on which the OECD area has depended for its growth, "positive adjustment policies" as recommended by the OECD's Council take on renewed importance. The OECD Observer asked Assar Lindbeck, Professor of International Economics at Stockholm's Institute for International Economic Studies, to give his views on these policies in the current context.
\end{abstract}

$\mathbf{T}$ he problem of adjusting production structures to new circumstances is a hotly discussed topic in most OECD countries at the present time. In an attempt to contribute to this discussion, five main points may be made.

\section{There is probably a greater need now than during the last two decades for the reallocation of resources in OECD countries.}

Two factors seem to be responsible. The first is that the developed OECD countries have recently undergone rather substantial changes in relative costs as between industrial sectors, in part because of dramatic shifts in the relative price of energy and stiffer standards for the protection of working conditions and the environment. A second factor is the emergence of a new international competitive situation - a more rapid change than before in nations' comparative advantage - due to the opening up of new, low-cost raw material sources ${ }^{1}$ and the building up of productive and technological capacity in previously lagging industrial countries, first in Japan and Southern and Eastern Europe and more recently in a number of less developed nations, the so-called newly industrialised countries (NICs).

It may be useful to cite five conceivable and closely related forces at work, some of which are linked to basic changes in technology and international trade, others which are "side effects" of widely accepted and often strongly motivated Welfare State reforms.

- While the post-World War II expansion of trade in manufacturing goods was mainly between developed countries, future growth may take place to an increasing extent between developed and less developed countries. Since there are greater differences in both relative factor prices and demand patterns between the developed countries and the LDCs than among individual developed countries, it can be expected that trade expansion within sectors, such as steel and automobiles, will to some extent be replaced by trade between sectors. Thus, while past expansion of world trade required in the main - though with some exceptions - reallocation of resources within sectors and within firms, future trade growth may require more reallocation of resources among sectors.

-While some sectors - agriculture, textiles and footwear for example - which have been on the decline in developed countries are dominated by rather small production units, some of those that now seem to be slated for contraction - steel, shipbuilding, certain chemicals and perhaps also automobiles - are more often characterised by large units. Sometimes these industries play a dominant role in a town or region, and the process of structural change, therefore, will generate local discontinuities and result in social problems which are both more visible and more dramatic than before.

- In political life, economic security and equality have been redefined during the Seventies. The dominant ambition to guarantee and equalise incomes and keep up a generally high level of employment has to a great extent been replaced by the aim of guaranteeing people's work in and income from exactly the same jobs they already hold. But this redefinition of economic security and equality implies that the labour market will lose much of its allocative flexibility as governments systematically have to "bail out" ailing firms. Legislative provision for seniority rights often works in the same direction: when an employee changes jobs he may lose these rights which then function like a tax on labour mobility - just as firmspecific pensions do - and accentuate the tendency of both the general tax system and of local subsidies (housing and child care, for instance) to hamper mobility. (In some countries, rent control and consequent malfunctioning of the housing market also hinder labour force mobility, but this is hardly a new phenomenon.
- In some countries, there has also been a deterioration in the allocative flexibility of capital markets, entrepreneurship and innovation. One reason for this is that income from "productive" risk capital is more heavily taxed than other assets. In fact, a basic (though probably unplanned) feature of the tax system in many OECD countries is that the highest real tax rates are applied to such assets as shares and industrial bonds which are likely to have the highest real returns. The result is to siphon savings and financial capital away from "productive" investment to public and private consumption, and to investment in stamps, works of art and other collectors' items. A second explanation is the proliferation of government controls such as interest-rate ceilings and portfolio regulations, the effects of which are often

(1) Obvious examples are iron ore (Brazil and Australia), bauxite (Australia), copper (Papua New Guinea), nickel (New Caledonia), uranium (Australia, Nigeria and Gabon) and in the future probably also pulp and paper (Southern US, Brazil and Portugal). 
sized firms as well and encourages the entry of new firms.

\section{But since political decisions} are to a great extent responsible for the lessened allocative flexibility of our economies, it is by no means obvious that the process can be reversed.

One could argue that better advice from economists, and a better informed general public, would improve policy; a committed adherent to the democratic process has, certainly, to be sympathetic to this idea.

But is such hope enough? The policies that have reduced the allocative flexibility of our economies may stem not so much from the "ignorance" or "stupidity" of politicians and the general public; it may be systematically embedded in the basic mechanisms of a highly competitive political system. A conceivable complementary strategy may therefore be to try to change the rules of the game in the political process, including political institutions and constitutional laws, on the grounds that existing rules seem to favour "immediate fixes" in the form of regulations and subsidies which may improve the short-term popularity of the government with certain pressure groups but also create severe long-term problems for society as a whole.

A main avenue for this "institutional approach" to a more flexible economic system would be to redesign some of the mechanisms of democratic decisionmaking, so as to facilitate decisions having a longer time perspective and stronger emphasis on the general interest, rather than that of specific groups of the population at the expense of the rest. Even to mention conceivable reforms of this type is to risk charges of naivety and lack of understanding of what is "politically feasible". However, one could argue that conceivable reforms may include longer election periods; more frequent use of public referenda on specific issues; large permanent coalitions of all major political parties in order to reduce party competition; greater independence for the central bank; and possibly an obligation to obtain qualified majorities for certain types of decisions such as the detailed regulation

Highly developed countries have a comparative advantage in innovation. Below: development of optical integrated circuits which could replace some electronic ones in long-distance telecommunications in connection with fibre optics.

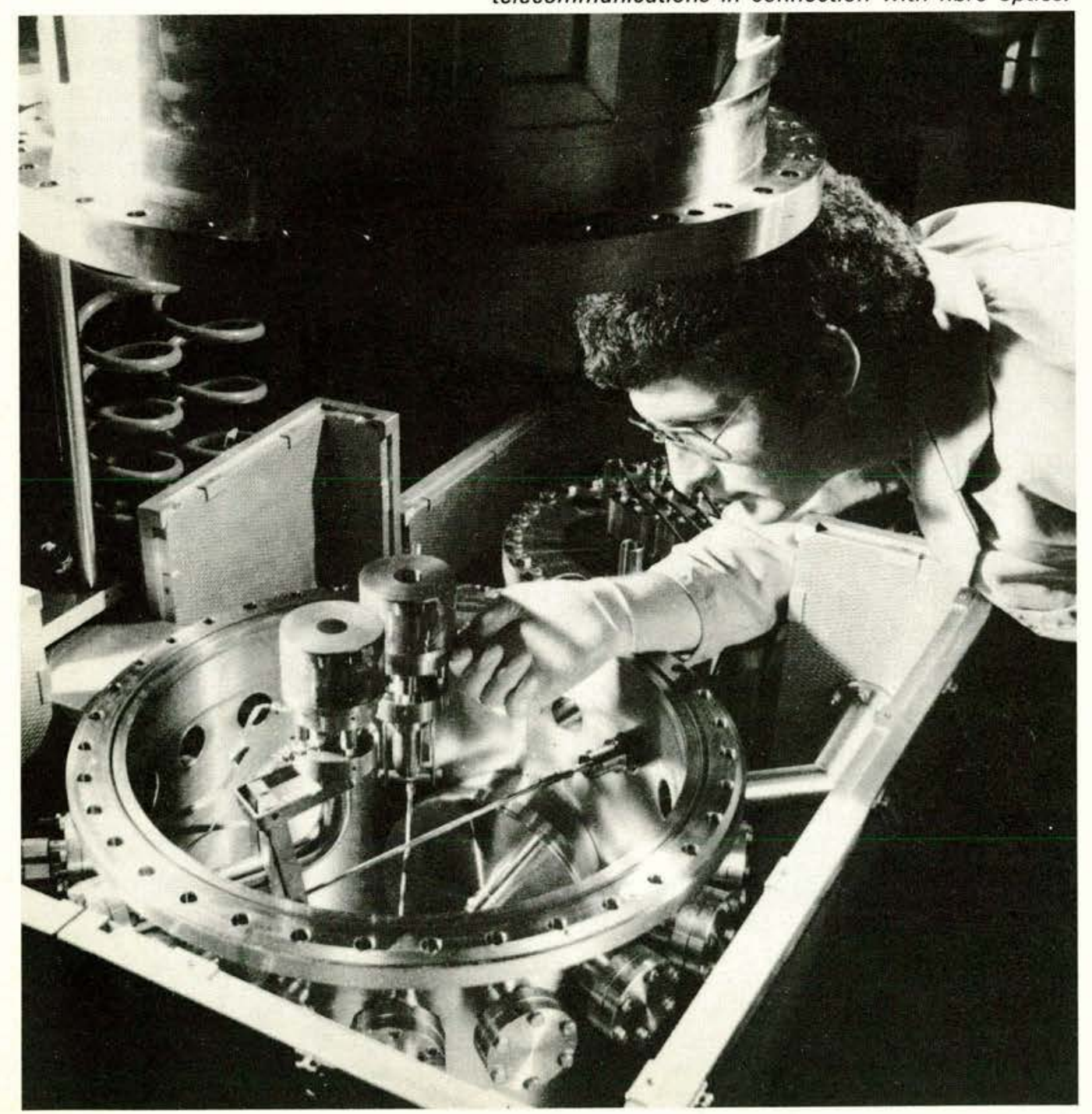

and subsidisation of individual firms and households.

Since many "policy-implemented" market imperfections are connected with increased public spending, it may also be worth considering the introduction of a rule that decisions to increase public spending should be combined with simultaneous decisions to raise taxes to finance that spending; wider use of fees for public services; refusal by the central government to collect taxes for municipalities when the latter have great autonomy on the expenditure side. All of these are conceivable methods for limiting public spending to what is consistent with what citizens want. Stricter international rules for the use of selective subsidies and other discriminatory measures should perhaps also be considered, probably within the context of the GATT.

To maintain that advocating political reform along lines like these is simply naive, risks perpetuating the present lack of flexibility of the Western economies.

\section{Is it not possible simply to con- clude that the OECD countries are now so rich that they can afford to do without further reallocation?}

Suppose that it proves impossible to increase the allocative flexibility of our economies through better informed decision-makers and publics or through reforms of the political decision-making mechanism? Would this make any difference?

When trying to answer this question, it is important to realise that such a strategy may not be a realistic option. In a world where the competitive situation on world markets is changing all the time, refusal to reallocate may result in gradually falling standards of living. Competition will simply send the "value added" in various productive sectors downwards - possibly to zero or even to negative figures. In some developed countries this has already happened - for instance in shipbuilding, where the market value of the intermediary product is now often higher than the market value of the ships produced. Thus, shipbuilding in some countries has become a negative production process in which excellent raw materials and intermediary products are turned into scrap, though this particular type of scrap is called "ships". If we want to avoid a similar development in other sectors - with the severe risk of gradually falling standards of living - we had better return to an economic system that is flexible enough to be able to reallocate resources. 


\section{Prospects}

For Recovery

\section{Highlights from the $O E C D$ Economic Outlook - December 1980}

The OECD economy has entered recession, with declining GNP likely to be recorded in the second half of 1980 in most major countries. On the basis of present policies and no substantial increase in the price of oil, the prospects are for a weak recovery starting in the first half of next year, to reach an annual rate of perhaps 3 per cent in the first half of 1982. Inflation seems likely to slow down progressively, although even by mid-1982 the rate in many countries is unlikely to have fallen back to that of 1978, before the series of oil price rises. Unemployment seems likely to rise sharply from around 23 million now to $251 / 2$ million, or nearly $71 \frac{1}{2}$ per cent of the labour force, although the rise could level off in the first half of 1982, largely as the result of buoyant employment growth in the United States. Current account deficits will probably diminish in the larger countries, with the United States moving into significant surplus, but may show little change in many of the smaller countries. The less developed countries without oil are likely to be in continuing large deficit, given the sluggish growth of their export markets, and some may face financing problems in view of their already large debt burdens. The forecasts depend importantly upon the assumption that business confidence will be broadly maintained, as well as upon the usual technical assumptions of no change in current or announced policies, real oil prices or nominal exchange rates. ${ }^{l}$

\section{Key Elements in the Forecasts}

\section{Inflation - the record and prospects}

The top priority in OECD countries is the reduction of inflation. The main instrument is aggregate demand management, the stance of which is tight in virtually all OECD economies. In this environment, price performance, as measured by the rise in consumption deflators (see Table 1), seems likely to improve over the coming eighteen months, provided there is no substantial increase in the real price of oil.

Nominal wage increases have generally accelerated in response to the oil price increases, although perhaps by $1 \frac{1 / 2}{2}$ to 2 percentage points less over the eighteen months to mid-1980 than would have been expected on the basis of past behaviour, implying a moderation of real wage growth in the face of the real income loss following the oil-induced terms-of-trade deterioration. Taking into account projected labour market developments, there may be some deceleration of nominal wage increases from now on, although an important exception is likely to be the United States, where the practice of multi-year wage contracts usually results in a delayed response of wages to prices. Produc- tivity growth seems to have weakened over the last six months or so in most countries, and the level of productivity may actually have declined in some, this being presumably an essentially cyclical phenomenon. A return to modest productivity growth is expected in most countries, although this is contingent upon the projected pick-up in output, and rates are likely to be low relative to the past. Profit margins seem to have been generally well maintained, although actual profits have fallen, particularly in manufacturing, due to the recession. If a wage catch-up is avoided and the projected path of output materialises, the share of profit in national income in most countries may return by mid-1982 to the 1978 level.

Domestically generated inflation (as broadly reflected by the rise of GNP deflators) seems likely to vary across countries. By mid-1982 it may be lower than in the second half of 1978 in a few, but in most it will probably be somewhat higher. Hence, while the acceleration of domestically generated inflation appears to have been contained, as compared with the experience following the $1973 / 74$ oil price rise, it nevertheless seems likely that the increase of around 150 per cent in the price of internationally-traded oil since the end of 1978 will have increased the rate of domestically generated inflation, perhaps by 1 percentage point for the OECD area as a whole. Whether this would represent a permanent increase in the underlying rate is, however, an open question.

Overall inflation which, measured by consumption deflators, also takes into account the effect of import prices, would seem likely, by mid-1982, to be more rapid than immediately before the oil-price rise in most countries, perhaps by $1 \frac{1 / 2}{2}$ percentage points for the OECD area as a whole. Although a rapid reduction of inflation is expected in a few countries, particularly Italy and the United Kingdom, the rate in those countries is still likely to be in, or close to, double figures in 1982. In North America, it seems likely to remain stubbornly high, at around 9-10 per cent. In Germany, there is the prospect of returning by 1982 to an inflation rate of around 3 per cent, which would be comparable to the rate in 1978. And in Japan, a 5 per cent inflation rate in 1982 would represent a return to the rate prevailing in the 1960s. Although price increases may slow down slightly from now on in most of the remaining OECD countries, in some they will remain in double figures.

\section{Income and demand}

The expected growth of nominal incomes, taken in conjunction with the prospective slowdown in imported inflation, seems likely, after a decline in the latter part of 1980 , to lead to gently accelerating growth of real pre-tax incomes. While the personal saving propensity has been showing sharp and hardto-predict short-term fluctuations in many countries, there seems no particular reason,

(1) The cut-off date for information used in the compilation of the Economic Outlook was November 17, well before the OPEC meeting at Bali. The assumption, a purely technical one, about oil price increases for 1981 is 11 per cent.

\section{EXTENSION OF}

\section{THE FORECAST PERIOD}

The forecast horizon in the Economic Outlook has been extended from 12 to 18 months ahead, thereby taking the forecasts in the current issue to the middle of 1982. This extension is meant to facilitate policy discussion, given that many economic processes, including the effects of policy actions, can take several years to work themselves out. However, the status of the assumptions built into the forecasts becomes more critical as the forecast period is extended, while the realism of the assumptions becomes more fragile. The interpretation of the assumption of unchanged monetary and fiscal policies, for instance, may be less easy to make for a period beyond that for which policies have been announced. The assumption of unchanged nominal exchange rates may also be more questionable once current balances and relative inflation rates have moved rather far from their initial positions. The estimates presented for the final half-year of the forecast period are, therefore, highly conditional and should be interpreted with caution. 


\section{PRIVATE CONSUMPTION DEFLATORS IN THE OECD AREA ${ }^{1}$ \\ Percentage changes seasonally adjusted at annual rates}

\begin{tabular}{|c|c|c|c|c|c|c|c|c|c|}
\hline & \multirow{2}{*}{\begin{tabular}{|c|} 
Average \\
1968 \\
to \\
1978
\end{tabular}} & \multicolumn{3}{|c|}{$\begin{array}{l}\text { From previous } \\
\text { year }\end{array}$} & \multicolumn{5}{|c|}{ From previous half-year } \\
\hline & & 1979 & $\begin{array}{l}\text { year } \\
1980\end{array}$ & 1981 & $I^{15}$ & $I I$ & $I^{19}$ & $I I$ & $\begin{array}{c}1982 \\
I\end{array}$ \\
\hline $\begin{array}{l}\text { United States } \\
\text { Japan } \\
\text { Germany } \\
\text { France }^{2} \\
\text { United Kingdom } \\
\text { Italy } \\
\text { Canada }\end{array}$ & $\begin{array}{r}5.9 \\
8.4 \\
4.8 \\
8.2 \\
11.4 \\
11.8 \\
6.5\end{array}$ & $\begin{array}{r}8.9 \\
3.1 \\
3.9 \\
10.9 \\
12.2 \\
14.8 \\
9.1\end{array}$ & $\begin{array}{r}101 / 2 \\
6^{1 / 4} \\
51 / 4 \\
13^{3 / 4} \\
151 / 2 \\
203 / 4 \\
93 / 4\end{array}$ & $\begin{array}{l}10 \\
51 / 4 \\
4 \\
11^{3 / 4} \\
12^{3 / 4} \\
15^{3 / 4} \\
10\end{array}$ & $\begin{array}{r}11.4 \\
6.4 \\
4.8 \\
14.3 \\
15.3 \\
24.3 \\
24.3 \\
9.6\end{array}$ & $\begin{array}{l}93 / 4 \\
6^{3 / 4} \\
5 \\
13 \frac{1 / 2}{12} \\
12^{1 / 4} \\
171 / 2 \\
10\end{array}$ & $\begin{array}{l}10^{1 / 2} \\
5 \\
4 \\
11^{3 / 4} \\
12^{1 / 4} \\
16^{1 / 4} \\
10\end{array}$ & $\begin{array}{c}91 / 2 \\
43 / 4 \\
31 / 4 \\
10 \\
12 \\
13 \\
93 / 4\end{array}$ & $\begin{array}{l}9^{1 / 2} \\
5 \\
3 \\
91 / 2 \\
9 \\
13^{1 / 2} \\
93 / 4\end{array}$ \\
\hline $\begin{array}{l}\text { Total of above countries } \\
\text { Other OECD countries }{ }^{3} \\
\text { Total OECD }\end{array}$ & $\begin{array}{l}7.0 \\
8.7 \\
7.2\end{array}$ & $\begin{array}{r}8.1 \\
11.0 \\
8.6\end{array}$ & $\begin{array}{l}101 / 2 \\
143 / 4 \\
11 \frac{1}{4}\end{array}$ & $\begin{array}{r}91 / 4 \\
121 / 4 \\
93 / 4\end{array}$ & $\begin{array}{l}11.0 \\
15.8 \\
11.8\end{array}$ & $\begin{array}{r}93 / 4 \\
41 / 4 \\
10 \frac{1}{2}\end{array}$ & $\begin{array}{l}92^{1 / 2} \\
12^{10}\end{array}$ & $\begin{array}{c}81 / 2 \\
111 / 4 \\
9\end{array}$ & $\begin{array}{c}81 / 4 \\
12^{1 / 4}\end{array}$ \\
\hline $\begin{array}{l}\text { Major seven countries } \\
\text { less the United States } \\
\text { Total OECD less the United States }\end{array}$ & $\begin{array}{l}7.9 \\
8.2\end{array}$ & $\begin{array}{l}7.4 \\
8.4\end{array}$ & $\begin{array}{l}10^{1 / 2} \\
11^{1 / 2}\end{array}$ & $\begin{array}{l}81 / 2 \\
91 / 2\end{array}$ & $\begin{array}{l}10.8 \\
12.1\end{array}$ & $11^{9^{3 / 4}}$ & $\begin{array}{l}81 / 2 \\
91 / 2\end{array}$ & $\begin{array}{c}73 / 4 \\
83 / 4\end{array}$ & $\begin{array}{l}71 / 4 \\
81 / 2\end{array}$ \\
\hline
\end{tabular}

(1) Aggregates were computed on the basis of 1979 values expressed in 1979 US dollars.

(2) Consumer price index not seasonally adjusted.

(3) Half-yearly data must be interpreted with care since for ten of these countries, amounting to over 50 per cent of the total GDP of the smaller countries, half-yearly growth rates were obtained by a purely mechanical interpolation.

\section{WAGE AND PRICE INFLATION IN THE MAJOR SEVEN COUNTRIES} Seasonally adjusted, annual rates - \%

\begin{tabular}{|c|c|c|c|c|c|c|c|c|}
\hline & $\begin{array}{l}1978 \\
I I\end{array}$ & \multicolumn{2}{|c|}{1979} & \multicolumn{2}{|c|}{1980} & \multicolumn{2}{|c|}{1981} & 1982 \\
\hline Compensation per employee & 9.0 & 9.2 & 10.0 & 11.1 & 10 & 10 & $93 / 4$ & $9^{1 / 4}$ \\
\hline GDP deflator & 7.8 & 7.6 & 8.2 & 8.4 & $10^{1 / 2}$ & $9^{1 / 4}$ & $81 / 2$ & $81 / 4$ \\
\hline Consumption deflator & 6.7 & 7.8 & 10.0 & 11.0 & $9^{3 / 4}$ & $9^{1 / 2}$ & $81 / 2$ & $81 / 4$ \\
\hline
\end{tabular}

\section{COMPONENTS OF INFLATION FOR THE MAJOR SEVEN COUNTRIES ${ }^{1}$ Percentage changes at annual rate}

Overall inflation (domestic demand deflator) of which:

(a) effect of terms of trade change

(b) domestically generated (GNP deflator)

of which, contribution due to:

(i) unit labour costs

resulting from:

compensation per employee productivity $(-)$

(ii) other influences, including profits per unit of ouput

\begin{tabular}{|c|c}
$1980 I$ & $\begin{array}{c}1982 I \\
1980 I\end{array}$ \\
\hline $1978 I$ & Forecast \\
\hline Actual & $83 / 4$ \\
8.9 & $-1 / 4$ \\
0.9 & 9 \\
8.0 & 5 \\
4.9 & $51 / 2$ \\
5.7 & $4^{1 / 2}$ \\
0.8 & \\
3.1 &
\end{tabular}

(1) This table provides an arithmetic decomposition of the components of inflation over the two periods. The "contribution" of each component has been calculated as the (annual) rate of growth weighted by its share in value added. These weights are typically around 0.6 for wages and salaries, and 0.4 for profits and the remaining elements.

taking one country with another, to expect any marked trend over the next eighteen months. The readiness of the corporate sector to invest is perhaps a greater uncertainty. Given the maintenance or likely restoration of profit shares in most countries, and the evidence that business confidence has been broadly maintained, to mid-1980 at least, it seems appropriate at present to project investment on the assumption that it will suffer no more than is customary in periods of weak demand. Exports to OPEC are likely to be a relatively buoyant demand component.
The most important remaining influence on aggregate demand may prove to be the stance of fiscal and monetary policy. After a probable slight swing towards restriction this year, the stance of fiscal policy, as indicated by estimated constant-employment budget balances, is projected (on the basis of present or announced policies) to move in 1981 towards greater restriction in most countries, perhaps by 1 per cent of OECD area GNP. This restriction is likely to be offset by the operation of automatic stabilisers, resulting in an increase in actual budget deficits in many countries. Monetary conditions are assumed to remain tight.

For the OECD area as a whole these various factors, taken together, will probably cause real post-tax income and expenditure to revert, after a fall in the latter part of 1980 , to modest growth over the next eighteen months, possibly reaching 3 per cent at an annual rate by the end of the period. This projection is based upon the assumption of no change in policies, and would also depend importantly upon there being no substantial change in the real price of internationallytraded oil and the maintenance of private sector confidence.

\section{Employment and unemployment}

The increase in demand would seem likely, given the projected generally weak trend of productivity, to result in a net addition of perhaps 3 million jobs in the OECD area as a whole. This gain could be made up of an increase of nearly 4 million jobs in North America and Japan, a loss of over a million jobs in the four largest European countries and smaller gains elsewhere in the OECD area. The net growth of employment would be insufficient to absorb the growth of the labour force in the OECD area, which may amount to 5 to 6 million over the next eighteen months. Unemployment forecasts are precarious, being dependent upon forecasts of real income, expenditure, productivity and labour-force participation rates. Nevertheless, unemployment in the OECD area increased in 1980, much as expected, by perhaps $3 / 4$ percentage point to $61 \frac{1}{2}$ per cent, and on the basis of the forecast behaviour of output and productivity may increase over the next 18 months by a further $2 \frac{1}{2}$ million, perhaps levelling off at around $251 / 2$ million, almost $7 \frac{1}{2}$ per cent of the OECD labour force, in the first half of 1982 . Such a rise would probably entail sharp increases in the number of unemployed young people, and a considerable lengthening of the duration of unemployment, resulting in a significant rise in longer-term unemployment (See Table 5 and page 14).

\section{External prospects}

In the absence of another oil-price increase, the OPEC surplus should fall substantially, but its counterpart is likely to be found mainly in the falling deficit of the larger OECD countries, with the United States likely to move to significant surplus. The deficit of many of the smaller OECD countries, however, seems likely to contract little over the next eighteen months. Non-oil 


\section{GROWTH OF REAL GNP/GDP IN THE OECD AREA \\ Percentage changes seasonally adjusted at annual rates}

\begin{tabular}{|c|c|c|c|c|c|c|c|c|c|}
\hline & \multirow{3}{*}{$\begin{array}{c}\text { Average } \\
1968 \\
\text { to } \\
1978\end{array}$} & \multicolumn{3}{|c|}{$\begin{array}{c}\text { From previous } \\
\text { year }\end{array}$} & \multicolumn{5}{|c|}{ From previous half-year } \\
\hline & & & & & \multicolumn{2}{|c|}{1980} & \multicolumn{2}{|c|}{1981} & \multirow{2}{*}{$\begin{array}{c}1982 \\
I\end{array}$} \\
\hline & & 1979 & 1980 & 1981 & $I$ & II & $I$ & II & \\
\hline $\begin{array}{l}\text { United States } \\
\text { Japan } \\
\text { Germany } \\
\text { France } \\
\text { United Kingdom } \\
\text { Italy } \\
\text { Canada }\end{array}$ & $\begin{array}{l}2.9 \\
6.6 \\
3.5 \\
4.4 \\
2.3 \\
3.4 \\
4.4\end{array}$ & $\begin{array}{l}2.3 \\
5.9 \\
4.5 \\
3.3 \\
1.5 \\
5.0 \\
2.8\end{array}$ & $\begin{array}{r}-3 / 4 \\
5 \\
13 / 4 \\
13 / 4 \\
-21 / 4 \\
33 / 4 \\
-1 / 2\end{array}$ & $\begin{array}{l}3 / 4 \\
33 / 4 \\
-1 / 4 \\
1 \\
-2 \\
-1 \\
11 / 4\end{array}$ & $\begin{array}{r}-1.4 \\
5.5 \\
2.8 \\
1.2 \\
-1.2 \\
6.4 \\
-1.9\end{array}$ & $\begin{array}{l}-13 / 4 \\
23 / 4 \\
-3 \\
1 / 2 \\
-5^{3 / 4} \\
-31 / 2 \\
-1 / 2\end{array}$ & $\begin{array}{l}1 \\
4 \\
1 / 2 \\
1 \\
1 / 2 \\
-1^{1 / 4} \\
13 / 4\end{array}$ & $\begin{array}{l}21 / 2 \\
4^{1 / 4} \\
1^{1 / 2} \\
2 \\
-2^{1 / 2} \\
2^{1 / 4} \\
2\end{array}$ & $\begin{array}{l}31 / 2 \\
43 / 4 \\
2 \\
21 / 4 \\
0 \\
21 / 2 \\
31 / 4\end{array}$ \\
\hline $\begin{array}{l}\text { Total of above countries } \\
\text { Other OECD countries } \\
\text { Total OECD }\end{array}$ & $\begin{array}{l}3.7 \\
3.9 \\
3.8\end{array}$ & $\begin{array}{l}3.4 \\
2.7 \\
3.3\end{array}$ & $\begin{array}{l}1 \\
11 / 2 \\
1\end{array}$ & $\begin{array}{l}1 \\
1^{1 / 2} \\
1\end{array}$ & $\begin{array}{l}1.1 \\
1.2 \\
1.1\end{array}$ & $\begin{array}{c}-1 / \frac{1}{1} \\
-3 / 4\end{array}$ & $\begin{array}{l}11 / 4 \\
11 / 2 \\
11 / 2\end{array}$ & $\begin{array}{l}21 / 4 \\
21 / 4\end{array}$ & $\begin{array}{l}3 \\
2 \\
3\end{array}$ \\
\hline $\begin{array}{l}\text { Seven major countries less } \\
\text { the United States } \\
\text { Total OECD less the }\end{array}$ & 4.4 & 4.3 & $2 \frac{1}{4}$ & 1 & 2.9 & -1 & $1 \frac{1 / 2}{2}$ & 2 & 3 \\
\hline $\begin{array}{l}\text { United States } \\
\text { Industrial production: }\end{array}$ & 4.3 & 3.8 & 2 & $11 / 4$ & 2.5 & $-1 / 2$ & $1 \frac{1}{2}$ & 2 & $21 / 2$ \\
\hline $\begin{array}{l}\text { Seven major countries } \\
\text { Total OECD }\end{array}$ & $\begin{array}{l}3.7 \\
3.7\end{array}$ & $\begin{array}{l}4.8 \\
4.7\end{array}$ & $-1 / 1 / 2$ & $\begin{array}{l}1 / 4 \\
1 / 4\end{array}$ & $\begin{array}{l}-0.3 \\
-0.1\end{array}$ & $\begin{array}{l}-61 / 4 \\
-5\end{array}$ & $2^{1 / 4}$ & $\begin{array}{l}23 / 4 \\
21 / 2\end{array}$ & $\begin{array}{l}43 / 4 \\
41 / 2\end{array}$ \\
\hline
\end{tabular}

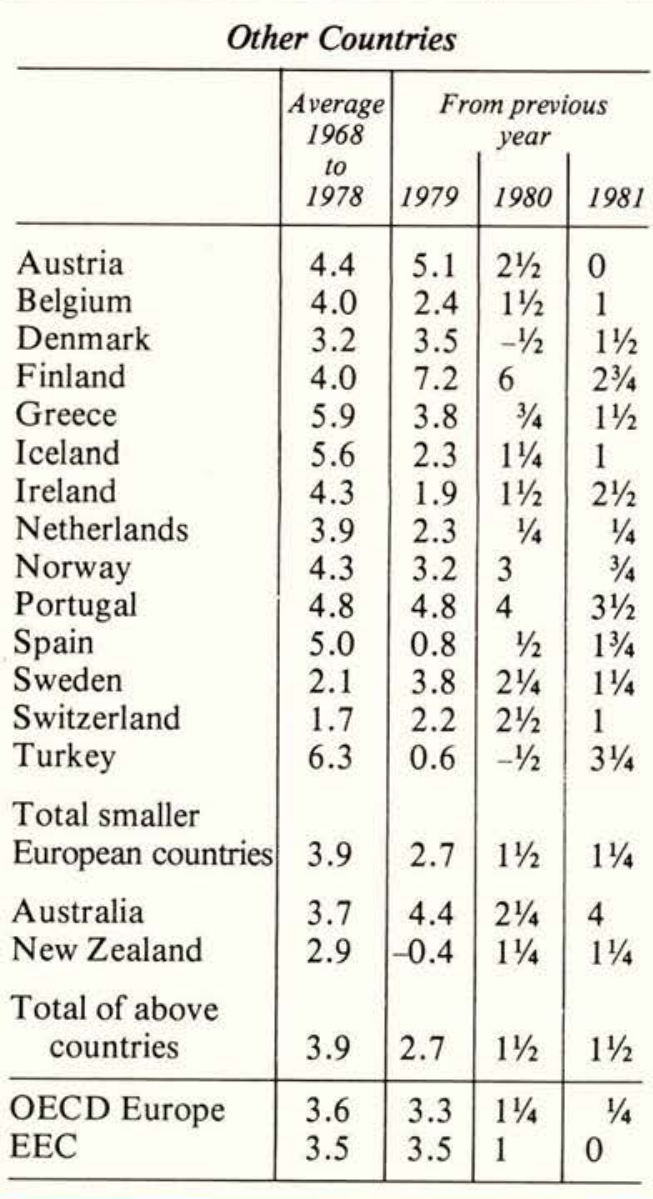

developing countries will probably face weaker export volume growth, which could be seriously exacerbated if there is an increased tendency towards protectionism. A widening current deficit could, in some instances, result in financing difficulties. The need for concessionary assistance will increase.

\section{Uncertainties and risks}

Past experience indicates the likelihood of substantial forecasting error after a major shock to the OECD economy, such as the the eighteen months to mid-1980. In many ways the problem is strongly reminiscent of 1973/74. A real income loss has been imposed upon the area, equivalent on each occasion to a little over 2 per cent of OECD GNP. This real income loss is virtually impossible to avoid, as are the direct inflationary impulse and, for several years, a large current account deficit vis-a-vis OPEC. But last time the policy response differed considerably across countries; this time the reaction, a tight stance of both monetary and fiscal policy, has been quite uniform.

Following 1973/74 some countries, including a number of the smaller ones, adopted a relatively expansionary fiscal stance to offset the deflationary effects of the OPEC surplus. But in the environment so created it did not prove possible to contain the inflationary impact, which soon became augmented by an upsurge of domestically generated inflation as money incomes rose in an attempt to pass on the terms-of-trade loss. The OECD current account deficit, the counterpart of much of the OPEC surplus, then became very unevenly distributed across OECD countries, with the high-inflation countries running relatively the largest deficits; this necessitated uncomfortably large external financing, and posed some debt-servicing problems for a number of them. Hence these countries had subsequently to rein in their domestic demand, just at the time that other, more cautious, countries, which had absorbed the oil price shock without as much second-round inflation, were able to take steps to expand. It was not until 1978, five years after the oil-price rise, that most countries were growing steadily again, albeit more slowly than in the halcyon days of the 1960s.

This time the uniformly tight monetary and fiscal stance looks as if it may prove relatively successful in containing the second-round inflationary consequences of the oil price rise, particularly in the major countries and, for the time being at least, the OECD area current deficit is distributed in a way that has not raised particularly difficult financing problems. But there has been, and continues to be, a substantial cost. GNP in 1981 will probably be $6 \frac{1}{2}$ per cent, some gripped firmly by the effects of the ine world oil prices of around 150 per cent over

\begin{abstract}
nal will probably be $61 / 2$ per cent, some
\end{abstract}

\section{POST-WAR UNEMPLOYMENT RATES IN SEVEN MAJOR COUNTRIES National definitions: historical statistics and forecasts}

\begin{tabular}{|c|c|c|c|c|c|c|c|c|}
\hline & \multicolumn{3}{|c|}{ Average } & \multicolumn{2}{|c|}{$1970-80$} & \multicolumn{3}{|c|}{ Forecasts } \\
\hline & $\begin{array}{l}1950- \\
1959\end{array}$ & $\begin{array}{l}1960- \\
1969\end{array}$ & $\begin{array}{l}1970- \\
1980\end{array}$ & $\begin{array}{c}\text { Lowest rate } \\
\text { (year) }\end{array}$ & $\begin{array}{c}\text { Peak rate } \\
\text { (year) }\end{array}$ & $1981 I$ & $1981 \mathrm{II}$ & $1982 I$ \\
\hline United States & 4.3 & 4.6 & 6.1 & 4.7 (1973) & $8.3(1975)$ & 8 & 8 & $73 / 4$ \\
\hline Japan & 2.0 & 1.3 & 1.7 & $1.1(1970)$ & $2.2(1978)$ & 2 & 2 & 2 \\
\hline Germany & 5.0 & 0.8 & 2.6 & $0.6(1970)$ & $4.1(1975)$ & 4 & $4 \frac{1}{2}$ & $4 \frac{3}{4}$ \\
\hline France & 1.8 & 1.5 & 4.0 & $2.4(1970)$ & $6.6(1980)$ & $71 / 2$ & $73 / 4$ & 8 \\
\hline United Kingdom ${ }^{1}$ & 1.2 & 2.0 & 4.6 & $2.5(1973)$ & $7.4(1980)$ & 10 & $11 \frac{1 / 4}{4}$ & $12 \frac{1}{4}$ \\
\hline Italy & 7.4 & 5.1 & 6.4 & $5.3(1974)$ & $7.8(1980)$ & $81 / 4$ & $81 / 2$ & $83 / 4$ \\
\hline Canada & 4.1 & 5.1 & 6.7 & $5.3(1974)$ & $8.3(1978)$ & 8 & $81 / 4$ & $81 / 2$ \\
\hline $\begin{array}{l}\text { Total of above } \\
\text { countries }\end{array}$ & 3.7 & 2.9 & 4.4 & $3.1(1970)$ & $5.8(1980)$ & $61 / 2$ & $63 / 4$ & $63 / 4$ \\
\hline
\end{tabular}

(1) Including school-leavers. 


\section{CURRENT BALANCES: SELECTED SUMMARY \\ $\$$ billion, seasonally adjusted, at annual rates}

\begin{tabular}{l|c|c|c|c|c}
\hline & 1979 & 1980 & 1981 & $1982 I$ & $\begin{array}{c}\text { Change 1979 } \\
\text { to } 1982 I\end{array}$ \\
\cline { 2 - 6 } United States & $-3 / 4$ & $51 / 2$ & $19^{3 / 4}$ & 15 & $15^{3 / 4}$ \\
Japan & $-8^{3 / 4}$ & $-13^{1 / 4}$ & $-6^{3 / 4}$ & -5 & $33^{1 / 2}$ \\
Germany & $-5^{1 / 2}$ & $-17^{1 / 4}$ & $-10^{1 / 2}$ & $-31 / 2$ & $22^{1 / 4}$ \\
Other major countries & -2 & $-11^{3 / 4}$ & $-71 / 4$ & -11 & -9 \\
Other North Europe & $-12^{1 / 2}$ & -23 & -20 & $-13^{3 / 4}$ & $-1^{3 / 4}$ \\
Other OECD & -6 & $-13^{3 / 4}$ & $-15^{1 / 4}$ & $-15^{1 / 4}$ & $-91 / 4$ \\
\hline Total OECD & -35 & -73 & -40 & -34 & 2 \\
\hline OPEC & 68 & 116 & 82 & 68 & 0 \\
Non-oil developing countries & -37 & -50 & -56 & -60 & -23 \\
Other & -3 & -5 & -8 & -13 & -10 \\
\hline
\end{tabular}

$\$ 550$ billion, lower than it might have been without the bout of oil price increases. Of this, tighter fiscal policies are likely to be responsible for OECD GNP in 1981 being 2 per cent lower than would have been the case had policy been neutral.

\section{The problems for policy}

By next year a number of countries may be in the position of having broadly maintained an acceptable relationship between costs and prices, and a few may no longer have any very serious inflationary problem. In due course, the latter may wish, given weak prospects for employment, capacity utilisation and investment, to lift somewhat the brakes on domestic demand growth. The scope for action may, however, be limited by the external constraint which at present bears heavily on the conduct of economic policy in all countries. Because of the high priority accorded to fighting inflation, there is a general tendency to resist any action which might lead to depreciation of the exchange rate, and there is even a certain willingness to accept currency appreciation, despite the implications for trade performance and the level of domestic activity. However, while a single country can retard imported inflation by tight policy such as tight monetary policy, which tends to raise interest rates and hence the exchange rate, there is a risk that if this were attempted by too many countries, monetary conditions would be tighter than generally warranted by purely domestic considerations, while having little or no effect on effective exchange rates and hence imported inflation. In such a circumstance, there might be a case for a different mix of fiscal and monetary policies. A generalised lowering of world interest rates might be preferable, so that low-inflation countries had interest rates more appropriate to their internal demand conditions, while the high-inflation countries maintained the requisite demand restraint through tighter fiscal policy. This would not necessarily be easy to achieve. Monetary changes can be executed quickly, but would need to be carefully co-ordinated, and fiscal changes often involve significant implementation lags. It would be important to avoid possible initially-adverse expectational effects. But the benefits, particularly on reducing the financing costs of investment, could be substantial, and warrant investigation.

In addition to the constraints acting on, and perceived by, countries individually, a further constraint currently bears upon aggregate activity in the OECD area considered as a whole. As a result of the Iran/Iraq war, the world oil market in 1981 is likely to be in approximate balance at best. Until the war is over and there are clear prospects of a more normal level of oil supply, any attempt at faster-than-forecast OECD area growth would almost certainly entail the risk of sharply rising oil prices, an increased OPEC surplus and accelerating OECD inflation, leading to lower GNP in 1981 than currently seems likely.

\section{Areas for action}

In these general circumstances, policy could usefully be directed at ensuring, first, that the energy constraint is eased as soon as possible, and second, that as this happens constraints internal to the OECD region or individual economies should also be alleviated, so that a more acceptable rate of growth can be resumed as soon as world conditions permit. Although there is no quick or easy solution, there are a number of areas in which action might be undertaken.

- Reducing dependence on imported oil. Considerable success has been achieved so far. Price- and regulation-induced conservation have resulted in a fall in energy use per unit of GNP in the OECD area of around 4 per cent over the last two years (See page 15). And energy production in the OECD area has increased by 4 per cent over the same period. As a result OECD net oil imports have fallen by about 10 per cent (almost $3 \mathrm{mbd}$ ). Unfortunately, because of the loss of production resulting from the Iran/Iraq war, the world excess of production over demand that earlier seemed likely, underscoring the need for yet further reductions in oil-dependence. And, even when more normal levels of supply return, strict and increasing economy of use will be needed if oil availability is not to oil market next year is unlikely to see the impart continuing inflationary and deflationary twists to the OECD economy.

- Weakening the links, particularly during an upturn in demand, between the level of macro-economic demand and the growth of nominal incomes. This requirement is not new. The list of possible instruments to influence the behaviour of nominal incomes, which includes a wide variety of prices and incomes policies, is regarded by many as a tired litany. But it seems clear, perhaps as never before, that the absence of a sufficient number of effective instruments has cost, and could continue to cost, the OECD economy dear. Some inflation is caused by excess demand, and can be eased only by changing the balance between demand and supply. But much of the inflation in many countries cannot be identified as having its origins in current excessive demand pressure, and seems to be able to persist despite slack demand. While a policy of fiercer deflation could no doubt further reduce inflation in these circumstances, its cost, in terms of foregone output, income and employment, could be very high, particularly if pursued without supporting policies. Government resolve to achieve monetary targets often has not had the full measure of hoped-for announcement effects on inflationary expectations. But present relatively modest wage behaviour suggests that there may be an improved understanding among income earners of the current policy dilemma facing countries. Efforts to maintain and strengthen this emerging consensus would seem essential, both to shorten as much as possible the period for which tight demand policies are necessary, and to prevent a wage acceleration and attempted "catch-up" when demand strengthens.

- Improving the supply-side response of economies. There is a growing body of opinion that over the last decade or two the plethora of regulations, controls and other impediments to the unfettered working of market economies, while introduced to achieve worthy ends, may have weakened the ability of economies to undergo structural change, as well as reducing their responsiveness to changes in aggregate demand. There would seem to be a case for taking a hard look at the evidence, with a view to seeing whether the ends sought can be achieved at less macroeconomic cost. More positively, there is often a role for policies to improve the working of markets and to encourage economic agents to accept changes in work and, perhaps, life styles. These policies would certainly include the preservation of an open trading order. While it would be inappropriate to expect too much too soon of supply-side policies, there would also seem to be a case for implementing measures to support productive investment so as to increase the sustainability of output growth in the medium term. Slow growth risks begetting slow growth, it is important that the early emergence of inflationary bottlenecks should be avoided when higher levels of demand are reached.

8th December 1980

(continued on page 14) 


\section{Special Features of the Economic Outlook}

\section{Youth Unemployment}

Youth unemployment rates are expected to rise sharply to the end of 1981 everywhere except in Japan, and to flatten out somewhat thereafter (see Table 7).

\section{FORECASTS OF YOUTH UNEMPLOYMENT, 1980-1982 \\ Per cent of youth labour force ${ }^{1}$}

\begin{tabular}{|c|c|c|c|c|c|}
\hline \multirow[b]{2}{*}{ United States } & \multicolumn{2}{|c|}{\begin{tabular}{|c|c|}
\multicolumn{2}{|c}{ Actual } \\
1978 & 1979
\end{tabular}} & \multicolumn{3}{|c|}{ Forecasts } \\
\hline & 11.7 & 11.2 & $13^{1 / 4}$ & 15 & 14 \\
\hline Japa! & 3.8 & 3.5 & $3 \frac{1}{2}$ & 4 & 4 \\
\hline any & 4.8 & 3.7 & 4 & $53 / 4$ & $6^{3 / 4}$ \\
\hline $\mathrm{Fr}$ & 11.0 & 13.3 & $14 \frac{3}{4}$ & $17^{1 / 2}$ & $18^{3 / 4}$ \\
\hline United $\mathrm{K}$ ingdom ${ }^{2}$ & 8.9 & 8.0 & 10.6 & $16^{1 / 2}$ & $201 / 4$ \\
\hline Italy & 24.8 & 25.6 & $271 / 2$ & $301 / 4$ & $32^{1 / 2}$ \\
\hline Canada ${ }^{3}$ & 14.5 & 13.0 & $13 \frac{1}{4}$ & $13 \frac{3}{4}$ & $14 \frac{1}{4}$ \\
\hline Total above & 10.8 & 10.5 & 12 & 14 & $14^{1 / 2}$ \\
\hline
\end{tabular}

(1) Aged up to 24.

(2) Data refer to July of each year. The 1980 figure is an actual rate not a forecast. The forecasts for 1981 and 1982 incorporate an adjustment for the proposed major expansion in the Youth Opportunities Programme.

(3) The armed forces are not included in the labour force aged 15-24.

\section{Duration of Unemployment}

An important consequence of higher unemployment rates is that spells of unemployment get longer. An analysis of this phenomenon is potentially important in assessing the amount of involuntary labour slack in an economy. Such an examination could throw light on the extent to which various levels and types of unemployment benefit may influence the duration of unemployment, and the extent of voluntary "search" and frictional unemployment (which will presumably be of short duration) as opposed to the involuntary deficientdemand and structural kinds which pose greater problems for policy. Unfortunately, readily available data refer to uncompleted spells of unemployment, and there is no straight translation from these figures to the more illuminating ones of the duration of completed spells.

These data (Chart A) show that the proportion of people unemployed who are out of work for three months or longer ("longerterm" unemployment) typically increases with the overall unemployment rate. There may also be something of a ratchet effect, in that while duration falls along with unemployment, it does so to a lesser extent. There was a widespread recession-induced jump in the proportion of longer-term unemployment in 1975, but in those countries where unemployment has subsequently fallen there has been a progressive fall in the ratio. That applies, for example, to the United States and Germany. In the United States, changes in longer-term unemployment have been entirely compensated for by corresponding changes in the proportion of very short-term unemployment (less than a month), leaving unchanged the proportion unemployed for 1-3 months. In other countries, however, where the unemployment rate continued to increase after 1975 (e.g. France and Belgium) or remained flat (the United Kingdom and the Netherlands) the proportion of longer-term unemployment has stabilised or even continued to increase. It now stands at 75 per cent of total unemployment for France and Belgium, just under 65 per cent in the Netherlands, and 61 per cent in the United Kingdom, levels which make "job search" or "frictional" explanations of the current high unemployment appear irrelevant.

The duration of unemployment is not only strongly cyclical but, as longer-term unemployment rises, the proportion accounted for by youths and prime-age workers also typically rises. The United States is an exception, but there youths make up an unusually high proportion of unemployment anyway. The share of longer-term unemployed in total youth unemployment has generally risen since 1976. The causes of this deterioration appear to be sluggish economic growth since the 1974-1975 recession and demographic factors because in some countries (e.g. the United States and the United Kingdom) the share of youth in the labour force has been growing very quickly.

In many countries older workers are customarily more than proportionately represented among the longer-term unemployed, but their share has clearly been falling except in Germany, in some countries helped by early-retirement options. At the same time, the share of longer-term unemployed in total unemployment of older workers has generally been increasing steadily. The rise in the percentage of prime-age workers in total longer-term unemployment could possibly

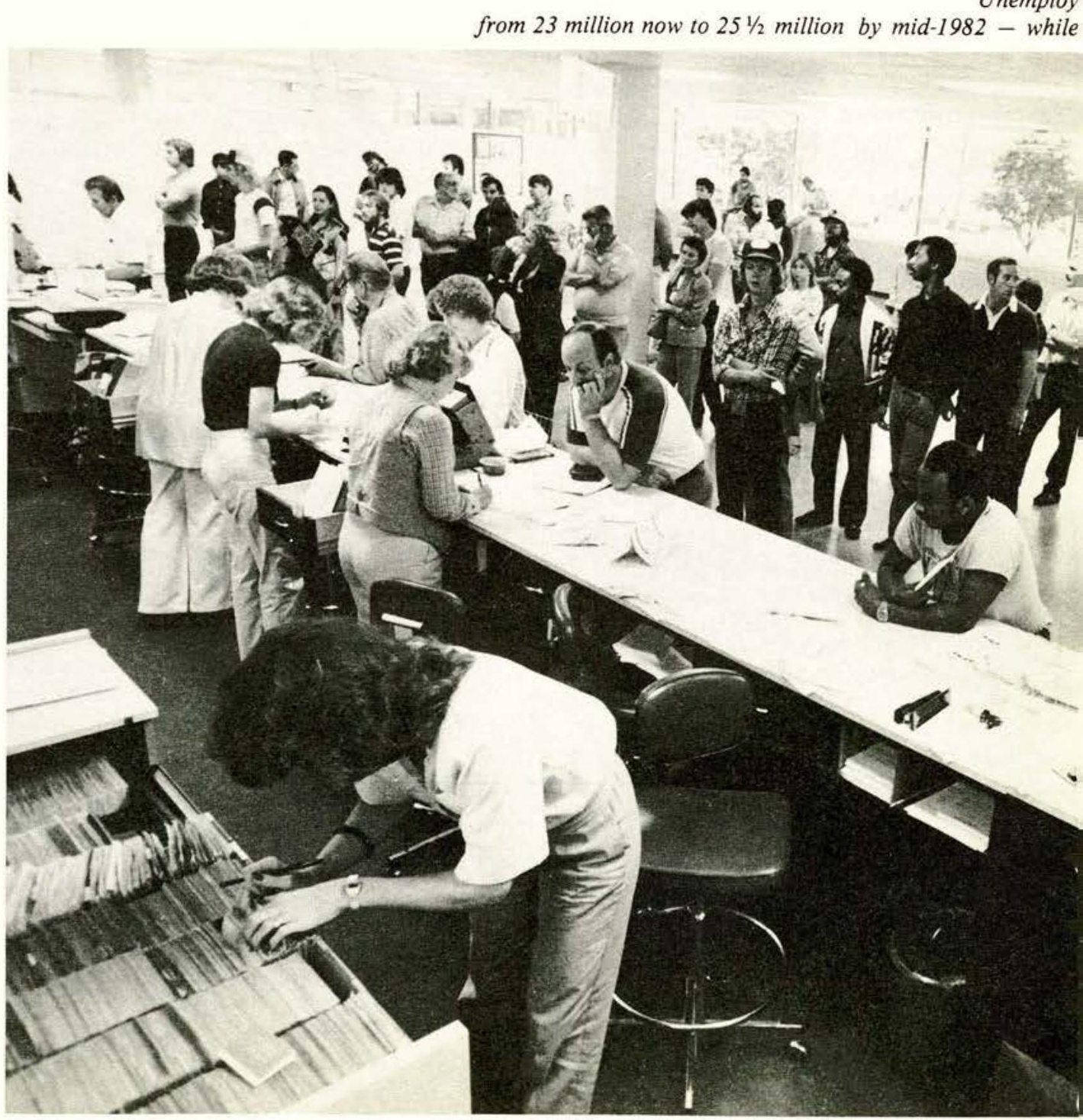


result from more favourable unemployment benefits in many countries as, in a period of sluggish activity and weak prospects of finding an appropriate job, these will both encourage registration and reduce the willingness of those on the register to accept less wellpaid jobs. Furthermore, if redundancy payments are made available for longer periods, this could increase the duration of registered unemployment. Nevertheless, the rise undoubtedly reflects the fact that labour market slack is increasingly affecting usually more-favoured groups, who are finding it harder to get a job once they are laid off. This conclusion is strengthened in many countries (e.g. Canada, France, the United Kingdom) by the trend in recent years to cut back on the proportion of average earnings replaced by unemployment benefits and to tighten up on eligibility conditions.

The proportion of women unemployed more than 3 months as a per cent of total longer-term unemployment has generally increased between 1973 and 1979. In the United States, the Netherlands and Norway, women accounted for between a third and a half of total longer-term unemployment in 1979. This development probably reflects higher female participation rates over the recent period, a tendency for employers to discriminate in favour of men at a time of widespread unemployment because of pre-

ment in the OECD area seems likely to rise sharply inflation may slow down somewhat-to around $9 \%$.

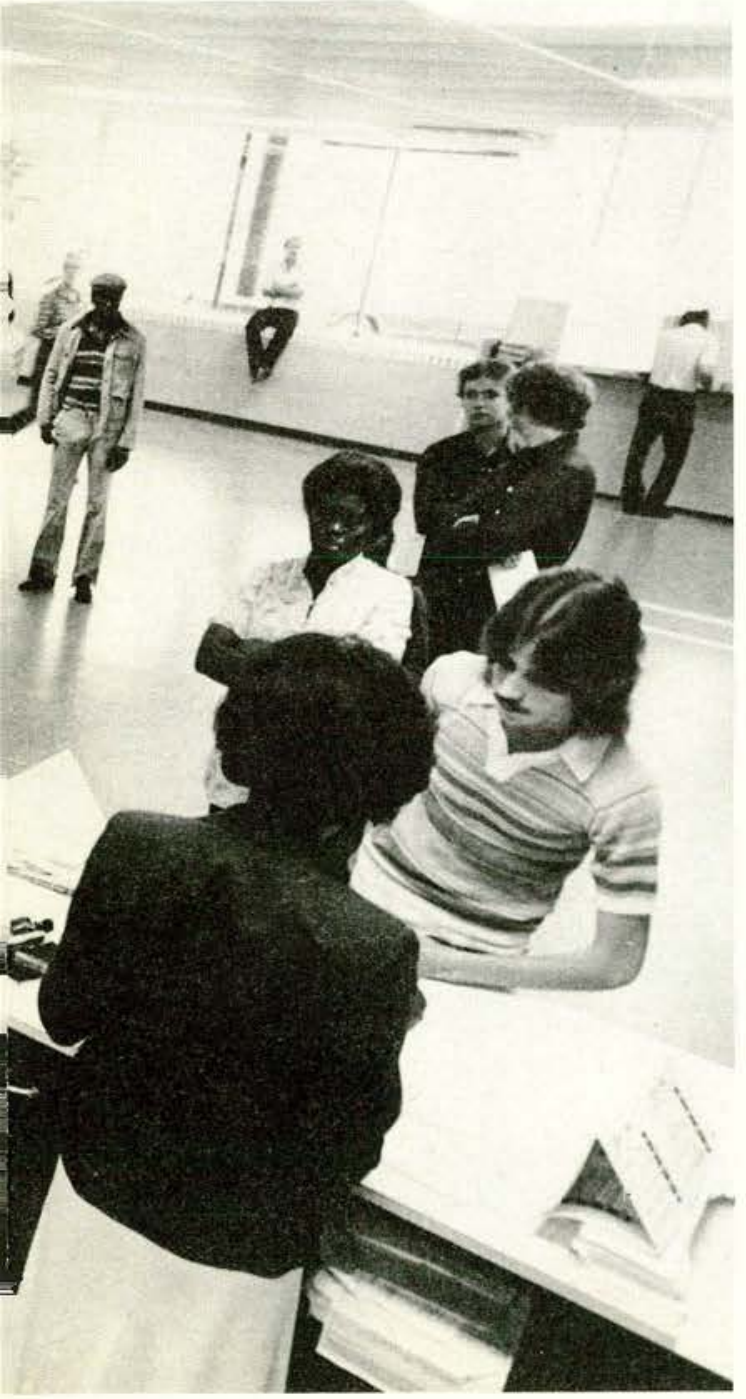

\section{A. DURATION OF UNEMPLOYMENT}

as per cent of civilian labour force
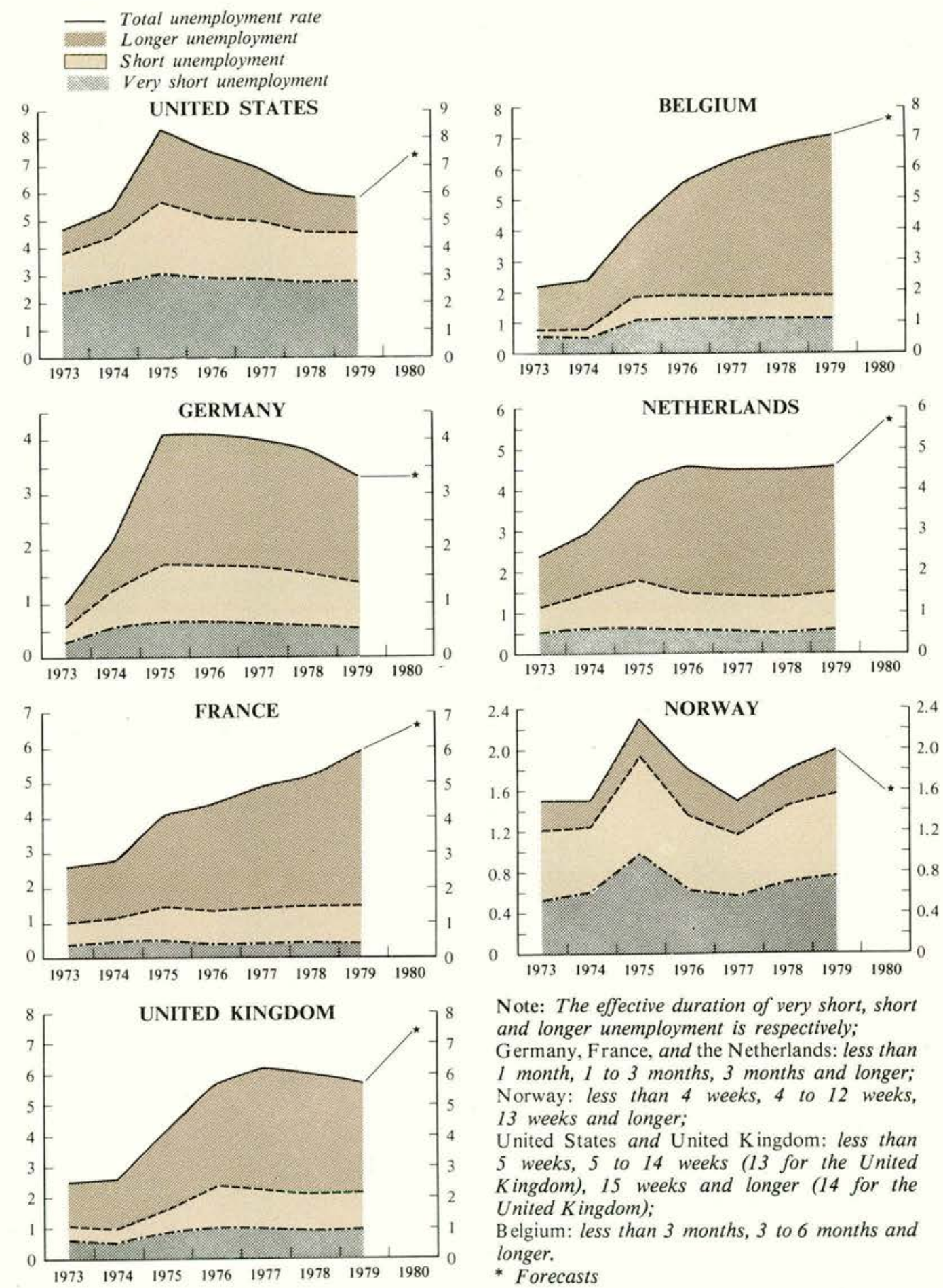

Note: The effective duration of very short, short and longer unemployment is respectively;

Germany, F rance, and the Netherlands: less than

1 month, 1 to 3 months, 3 months and longer;

Norway: less than 4 weeks, 4 to 12 weeks,

13 weeks and longer;

United States and United Kingdom: less than 5 weeks, 5 to 14 weeks (13 for the United Kingdom), 15 weeks and longer (14 for the United Kingdom);

Belgium: less than 3 months, 3 to 6 months and longer.

* Forecasts conceptions about their role as "breadwinners", and a high degree of occupational specialisation; women are concentrated in some particularly hard-hit sub-sectors of manufacturing, e.g. textiles and clothing, where they account for 70 per cent of the workers.

\section{Energy Prices and Demand}

A rise in the import price of oil increases inflation in a number of ways: it raises the energy components of the consumer and wholesale price indices, oil being a consumption good and an input into the production process; furthermore, prices of domesticallyproduced oil follow suit, as do prices of competing fuels, such as natural gas and coal, after some lag.

The speed at which prices of domesticallyproduced energy and prices of competing fuels adjust to a rise in the import price of oil differs by type of fuel, between countries and over time. A broad measure of the overall sympathetic price adjustments is provided in Table 8 , where the percentage increases in the energy components of consumer and wholesale price indices have been divided by import prices of oil (expressed in local currency). While the level of the pass-through ratios cannot be compared across countries 


\section{PASS-THROUGH RATIOS}

Change in energy prices to final users relative to the rise in import price of oil ${ }^{1}$

\begin{tabular}{|c|c|c|c|c|c|}
\hline & 1973-75 & $1978-80$ & & $1973-75$ & $1978-80$ \\
\hline UNITED STATES & & & UNITED KINGDOM & & \\
\hline EWPI & 0.39 & 0.69 & EWPI & 0.28 & 0.51 \\
\hline ECPI & 0.17 & 0.42 & ECPI & 0.29 & 0.55 \\
\hline Total & 0.23 & 0.50 & Total & 0.28 & 0.53 \\
\hline JAPAN & & & ITALY & & \\
\hline EWPI & 0.60 & 0.81 & EWPI & 0.77 & 0.58 \\
\hline ECPI & 0.17 & 0.31 & ECPI & 0.24 & 0.54 \\
\hline Total & 0.35 & 0.57 & Total & 0.42 & 0.56 \\
\hline GERMANY & & & CANADA & & \\
\hline EWPI & 0.20 & 0.29 & EWPI & 0.17 & 0.41 \\
\hline ECPI & 0.16 & 0.32 & ECPI & 0.16 & 0.20 \\
\hline Total & 0.18 & 0.31 & Total & 0.16 & 0.27 \\
\hline FRANCE & & & SEVEN MAJOR COUNTRIES & & \\
\hline EWPI & 0.27 & 0.48 & EWPI & 0.38 & 0.63 \\
\hline ECPI & 0.20 & 0.39 & ECPI & 0.18 & 0.40 \\
\hline Total & 0.23 & 0.42 & Total & 0.24 & 0.48 \\
\hline
\end{tabular}

Note: These ratios are calculated successively for the energy component of wholesale prices (EWPI), the energy component of consumer prices (ECPI), and the total, giving to EWPI a weight equal to the share of industry in total final energy demand.

(1) In local currency. For Canada, the import price of oil has been replaced by the import price of energy (fob). (the coverage of energy prices being different), this table provides firm evidence that the sympathetic price adjustments have become quicker over time. Tentative estimates suggest that a 10 per cent rise in the import price of oil raised energy prices to final users by $4 \frac{3}{4} 4$ per cent in 1978-1980 (compared with just over 2 per cent in 19731975).

Principal elements in the rise in the passthrough ratio have been: a more rapid response of natural gas prices (the main competing fuel); decontrol of prices of domestically-produced oil and natural gas in the United States; special taxes on final energy use; and a faster adjustment of electricity tariffs. These factors can be related to the perceived need to reduce oil import dependence and, probably, to revised expectations concerning the future price of oil.

Reflecting the higher pass-through of oil import prices to energy prices to final users, relative energy prices $^{1}$ in the seven major countries may have risen by 33 per cent from 1978 to 1980 , compared with 25 per cent in 1972-1975 (Table 9). Consequently, final energy demand is likely to react at least as

1. Relative energy prices to final users are measured by the energy component of the wholesale and the consumer price indices divided by the total index excluding the energy component.

\section{B. FINAL ENERGY DEMAND AND RELATIVE ENERGY PRICES TO FINAL USERS IN THE PERIOD 1972-80 $1972=100$}

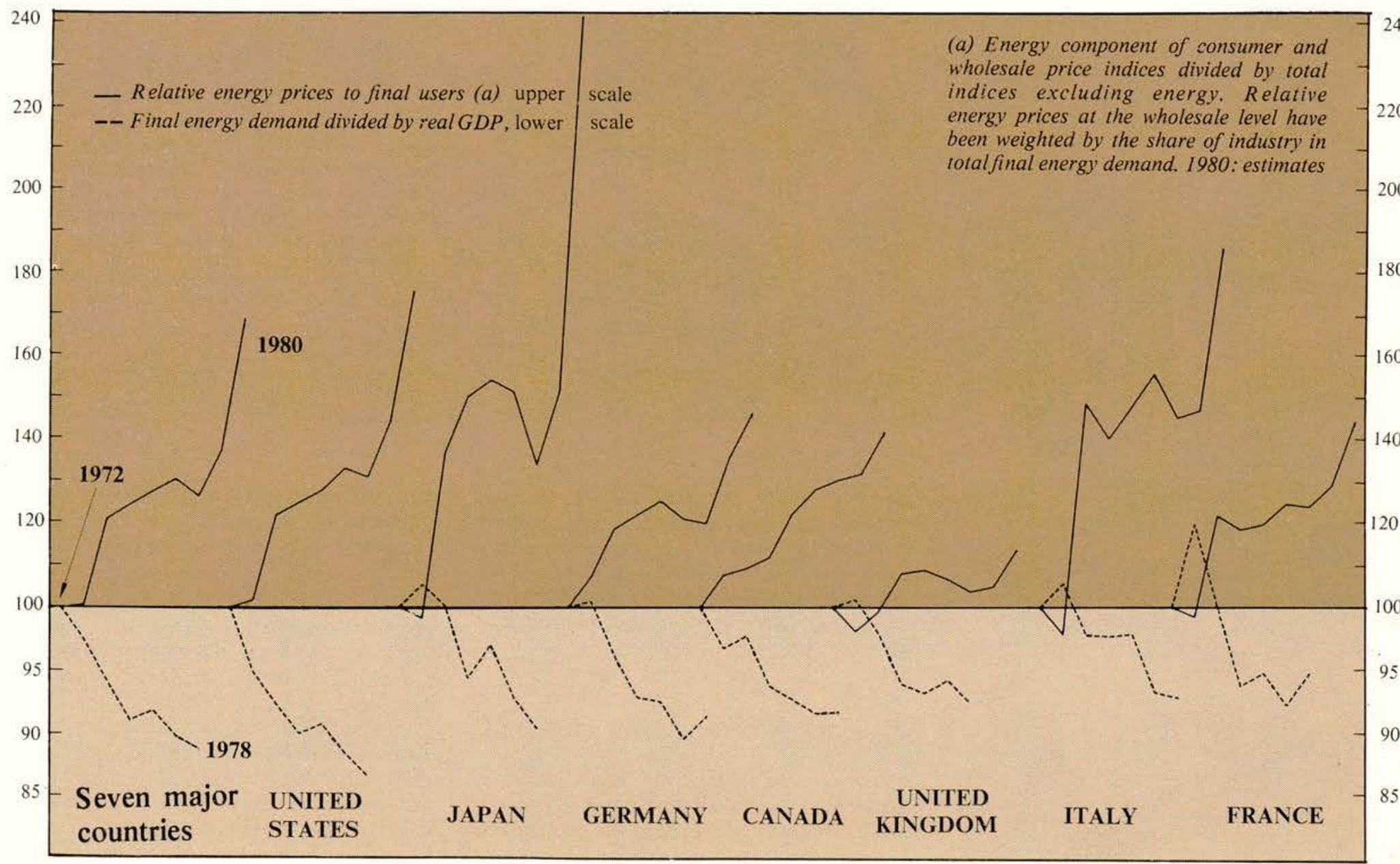




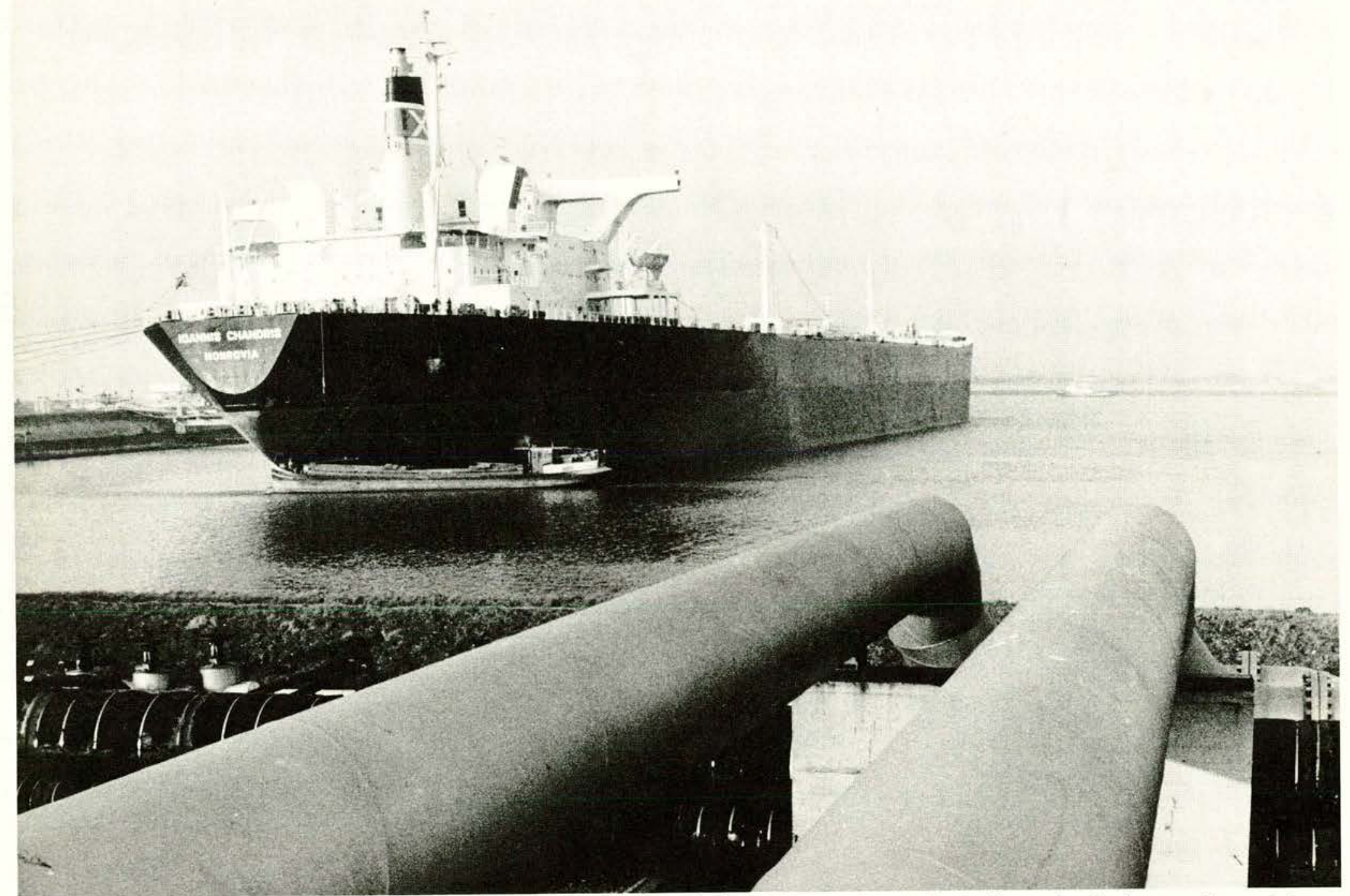

In the last two years, more of the increase in the price of imported oil has been passed on to the final user than in the preceding period.

strongly to the rise in energy prices, over the medium term, as it did after the first oil price shock. Tentative calculations suggest that the rise in relative energy prices to final users after the first oil price shock, combined with non-price measures, lowered final energy demand by 230 million tons of oil equivalent (mtoe) below the level which would otherwise have prevailed. In terms of primary energy demand (before losses in the energy-producing sector) this corresponds to $6 \frac{1}{4}$ million barrels a day of oil equivalent ${ }^{2}$.

In Chart B the seven major countries are grouped according to the fall in energy use, as

\section{RELATIVE ENERGY PRICES TO FINAL USERS ${ }^{1}$ $1972=100$}

\begin{tabular}{l|c|r|r|r|r|r|r|c}
\hline & $\begin{array}{c}\text { United } \\
\text { States }\end{array}$ & Japan & Germany & France & $\begin{array}{c}\text { United } \\
\text { Kingdom }\end{array}$ & Italy & Canada & Total \\
\hline 1973 & 101.7 & 97.3 & 107.2 & 97.7 & 94.1 & 93.4 & 107.7 & 100.6 \\
1974 & 122.0 & 137.1 & 118.7 & 122.0 & 98.9 & 148.9 & 109.2 & 121.3 \\
1975 & 125.1 & 150.5 & 122.1 & 118.7 & 108.0 & 140.4 & 111.9 & 124.6 \\
1976 & 128.0 & 154.5 & 125.5 & 119.9 & 108.9 & 148.1 & 122.3 & 127.8 \\
1977 & 133.2 & 151.5 & 121.1 & 124.8 & 106.7 & 156.0 & 128.1 & 130.7 \\
1978 & 131.1 & 134.0 & 120.0 & 124.1 & 103.7 & 145.5 & 130.5 & 126.6 \\
1979 & 144.7 & 151.8 & 135.8 & 129.3 & 104.9 & 147.3 & 131.9 & 137.6 \\
$1980^{2}$ & 175.6 & 241.7 & 146.4 & 144.4 & 113.6 & 186.2 & 141.8 & 169.0 \\
\hline
\end{tabular}

(1) Energy component of consumer and wholesale price indices divided by total indices excluding energy. Relative energy prices at the wholesale level have been weighted by the share of industry in total final energy demand.

(2) Estimates. measured by the ratio of final energy demand to real GDP, between 1972 and 1978. Countries with large reductions in this ratio have, on the whole, been those with comparatively strong increases in relative energy prices to final users. There are two main exceptions, Japan and Italy, where a large rise in relative energy prices produced small reductions in demand. In both countries, especially in Japan, industrial final energy demand accounts for a large share of total final energy demand. Given the low specific energy taxes in industry, industrial energy prices are more sensitive to changes in the import price of oil than energy prices in the household sector. However, empirical studies have shown the price elasticity of industrial final energy demand to be lower than that in the residential/commercial sector. Consequently, when oil import prices rise, countries with a large share of industrial use in total final energy demand experience both comparatively large increases in relative energy prices at the aggregate level and comparatively low reductions in energy intensity.

2. This estimate is based upon an income elasticity for final energy demand of 0.85. It does not allow for the lagged effects which falling relative energy prices prior to 1972 may have had on final energy demand. 


\section{IEA Ministers Tighten Up on Oil}

I EA Ministers have completed a meeting which focussed primarily on the equitable distribution of oil in times of "precrisis". They agreed on a package of measures aimed at minimising pressures on the oil market by reducing IEA demand on world oil markets by about 26 million tons or 2.2 million barrels a day in the first quarter of 1981, apart from the normal seasonal stock-draw. The package of measures agreed upon includes five parts:

1. Ministers agreed to continue to draw on stocks as necessary to maintain a balance between oil supply and demand. If stocks were to be used to make up for the total shortfall expected in the first quarter - about $2.2 \mathrm{mbd}$ - then stock levels would fall from their 1st October level of 460 million tons and their 1st January 1981 level of 440 million tons to 385 million tons by 1 st April of 1981 . This level would still be somewhat higher than stocks on 1 st April, 1979 of 364 million tons.

2. In order to minimise as much as possible stock draw of this magnitude, Ministers agreed to take action to further reduce demand which is already about 6 per cent less than last year's. Here it is up to the discretion of each country what actions to take. But those with unusually low levels of stocks or reduced supply from the Iraq-Iran conflict may have to take stronger measures than others.

3. Those countries with indigeneous production of oil and gas agreed to encourage and to support high levels of indigenous oil and gas production in their countries.

4. All nations agreed to discourage undesirable purchases of oil at prices which have the effect of increasing market pressures.

5. Ministers agreed to try to even out imbalances which might arise between countries and in some cases between companies. The aggregate stock and supply position of IEA countries is manageable, but some serious imbalances in the distribution of stocks and supplies in IEA countries might develop. It has been agreed in principle that those countries which are in a more favorable position will contribute to easing market pressures in those countries with a less favourable supply and/or stock situation. The IEA is not implementing a formal allocation system; but rather a system which will help

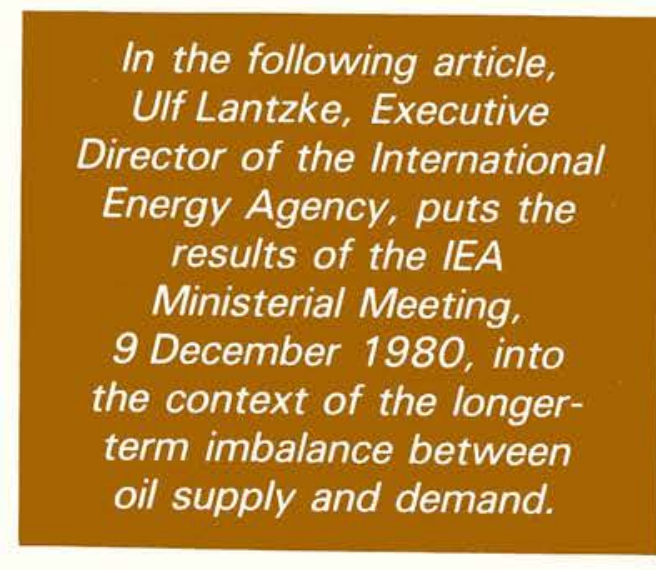

overcome problem cases - in either countries or companies. These could lead, if uncorrected, to undue pressure on markets which, in turn, could lead to higher prices.

We expect that these actions will reduce IEA oil demand on world oil markets during the 1 st quarter of 1981 to 238 million tons, compared to forecasts of 264 million tons. This amounts to reducing oil demand on world markets by about $2.2 \mathrm{mbd}$ throughout the first quarter and is consistent with what is expected to be available to IEA countries over this period. For these actions to be credible, Ministers concluded by agreeing that these actions must and should be implemented as soon as possible and charged the Governing Board of the IEA to meet regularly to review progress in implementation.

\section{Background of the Current Measures}

To understand why the measures were taken, one must go back a bit in history. Over the last ten years, there have been three major disruptions in oil supply caused by the Arab-Israeli war of $1973 / 74$, the Iranian revolution of 1979 , and the current conflict between Iran and Iraq. It is instructive to look at how oil prices, supplies and demand patterns have adjusted to these oil market disturbances.

\section{$1973 / 74$}

In 1973 when the first oil shock hit, governments really had no contingency plans for dealing with the problem. The market distribution during that time of crisis was handled primarily by the international oil companies who, contrary to what is widely believed by the public, responded in a very responsible and effective way to help stabilise the world oil market system.

As a result of the shock of 1973 and 1974, governments decided to establish better cooperative means to meet any future crisis. Thus, major consuming nations agreed to an International Energy Program and established the IEA to implement it.

The central feature of the initial work of the IEA and indeed still one of its major purposes is the emergency sharing system. The system can be triggered at any time the Group or a country selectively are faced with a 7 per cent shortfall of supplies. Tools for managing the oil market in such circumstances include demand restraint, stock draw and, when necessary, reallocation of supplies from one country to another. The intent is to even out in a cooperative way the severity of a given crisis.

\section{9}

In 1979, we were faced with a problem which was quite different in nature from the 1973/74 embargo. The revolution in Iran resulted in a substantial reduction in oil output, but within a few months other OPEC countries had replaced most of the lost Iranian production. However, for some time there was a shortfall of about $2 \mathrm{mbd}$ and this temporary shortfall caused prices to more than double within a year; it was not so much the actual physical shortfall, but the perception of further supply stringencies which caused prices to escalate so rapidly.

Thus in thinking about equitable distribution of oil supplies in a crisis, we must not only envisage strategies for coping with actual physical shortage but also consider strategies for reducing pressures - real and perceived - on oil markets during these periods to help stabilise prices. In fact the longest period of actual shortage we have experienced so far is only about three months.

In 1979, most of the initial shortfall was met through increased production by other OPEC producers and demand restraint in consuming nations. Later in the year lower economic growth contributed to reduction in demand. The price increase of almost 140 per cent was brought about by a 
relatively small shortfall which set in motion a chain reaction of events keeping OECD demand for OPEC oil at a high level until the summer of this year. The psychology of supply uncertainties resulted in less than optimum cooperation between the consuming countries. There were several examples of consuming countries adding somewhat to the build-up of market pressure:

- Some countries built stocks at a pace that put added pressure on spot market prices.

- Others established state oil companies to deal directly with producers in the hope of obtaining additional supplies. The increase in state-to-state deals reduced the flexibility of traditional supply channels.

- Some economies appeared ready to pay a very high price for oil rather than make energy cutbacks that would be politically difficult and in their view damaging to their economies.

- Changes in traditional patterns of supplies aroused some heated debate between the United States and European countries after the US imposed a $\$ 5$ entitlement programme to redirect oil supplies from the Rotterdam market, where spot prices were highest, back to the Caribbean.

In response to such a situation, the IEA and the Tokyo Summit both tried to implement measures which would reduce competition among industrialised nations. IEA countries in March of 1979 set an overall objective - to reduce their oil demand on world oil markets by 5 per cent. This action was followed by the Tokyo Summit which adopted the concept of oil import ceilings. But these mechanisms were still not sufficient. Why was the general response inadequate?

- The IEA decision to reduce oil demand on world oil markets was too general and probably should have been taken by Ministers who could have encouraged stronger implementation at Cabinet level.

- The Tokyo Summit helped to identify more precisely individual contributions to overcoming the problem by adopting individual oil import ceilings. However, the oil import numbers were somewhat inflated, and no effective means for monitoring compliance was implemented. (After about a year's effort the IEA in May 1980 established a system for oil-import ceilings which will permit more effective and consistent implementation of this important option when and if it becomes necessary).

- Where supply and demand for the IEA as a whole was relatively balanced, some nations were less well off and had to enter the spot market for some cargoes. This, coupled with continued stock building by some countries already in a relatively comfortable position, put severe pressure on markets.

\section{The Record since 1973}

Prices have increased just about tenfold (in 1970 dollars) from 1973 to the present.

OPEC exports have declined from about $30 \mathrm{mbd}$ in 1973 to an estimated 26 in 1980. Most of this decline has been during the last year.

Imports into IEA countries have declined from over $24 \mathrm{mbd}$ in 1973 to an expected 22 in 1980.

Overall oil consumption in the OECD area has remained relatively level. The principal reasons for declining OECD imports from OPEC are: a substantial increase in OECD oil production, rising imports from nonOPEC sources including Mexico, fuel substitution, and declining oil use due to conservation and most recently a reduction in economic activity.

- Few attempts were made to collectively discourage undesirable purchases, even those with very high premiums.

- Lastly - and this is not a criticism but an observation - companies which had gener-

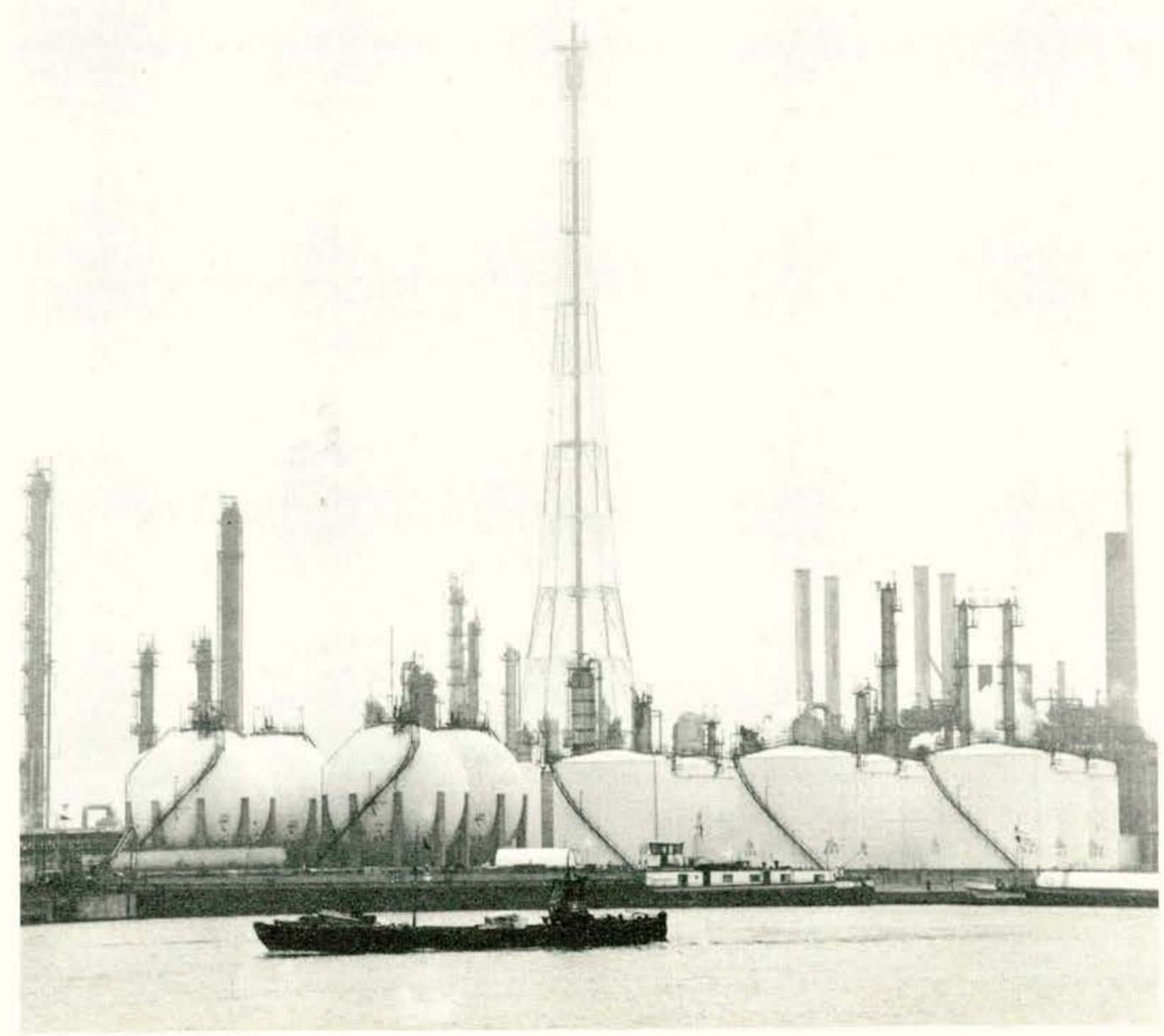

ally put a very high priority on maintaining the balance of the world oil market system in 1973/74 obviously placed a much higher priority on consolidating individual company positions in 1979.

Thus while oil supply and demand were in fragile balance throughout most of the year, the competitive attitudes gave oil producers the impetus to increase prices some 140 per cent. This, according to OECD estimates, will have a cumulative effect of reducing OECD GNP by some $4 \frac{1}{2}$ percentage points by the end of 1981 . This means that total OECD GNP by the end of 1981 will be almost $\$ 400$ billion (or almost $\$ 500$ per capita per a year) below what it might have been if oil prices had remained stable in 1979 and 1980.

\section{The Situation Today}

Clearly we cannot afford to repeat the experience of 1979. Yet there are some important similarities between the situation we faced in the early part of that year and the situation we face today. Firstly, the anticipated shortfall is of about the same magnitude - about 1 to 2 mbd. Secondly, some of the warning signs are again rather clear: swelling and erratic price movements in the spot market coupled with added surcharges to official prices by some OPEC producers and the willingness of some oil

\section{IEA countries have agreed to draw on stocks in the first quarter of 1981 to reduce pressure on
the oil markets. \\ IEA countries have agreed to draw on stocks in the first quarter of 1981 to reduce pressure on
the oil markets.}


companies to pay these surcharges in exchange for term contracts. However, an important difference between 1979 and the current situation is that overall IEA stock levels are much higher.

Over the last three months IEA countries have collectively established a strategy to deal with the oil market in quite a different manner than previously.

On 1st October 1980 - a very quick response this time - IEA countries agreed to lower their stocks. Our statistics reveal that stock draw does in fact seem to be taking place - at a rate of about $2.5 \mathrm{mbd}$. This, coupled with increased production from some producers of more than $1 \mathrm{mbd}$, made up for most of the $4 \mathrm{mbd}$ of Iraqi and Iranian oil exports the world has lost.

Yet regrettably the hostilities in the Middle East have not disappeared and while the measures of 1 st October have been successful to date in moderating price increases, it was felt that Ministers needed to meet to take further action.

I am confident that the new measures will work and that pressures on prices will be reduced. We all hope for an early resolution of the conflict between Iran and Iraq. That is the best solution for calming oil market concerns. On the other hand, if the active conflict continues, Ministers may have to meet on short notice if it becomes necessary.

Perhaps the most fundamental difference between our response in 1979 and now is that we are attempting to put in place means for stabilising the situation at an early stage rather than having to react to bigger problems later.

\section{Longer Term Energy Issues}

Ministers at their meeting also looked into a number of longer term energy issues. We have tried to keep these issues in the forefront because, unless effective action is taken to promote structural changes in energy economies to reduce our dependence on oil, our nations will remain vulnerable to short-term disruptions in the oil market. And, as we have learned in the 1970s and early 1980, any number of events can upset the fragile balance of the world oil market. The only true surprise would be if there are no surprises over the coming years.

First, bringing on alternative sources of energy takes time. And, even with significant efforts, oil as a percentage of total energy is only likely to be reduced from 50 per cent today to 40 per cent by the year 1990. If we can really get behind coal and nuclear energy, then it is possible that oil as a percentage of the total energy balance can be reduced to 30 per cent by the year 2000 . This would require a tripling of coal production and use (see below) and a five-fold increase in nuclear energy. Such an increase on the supply side, coupled with continuous efforts to use energy more wisely would result in a decline of IEA imports from $24 \mathrm{mbd}$ in
1978 to 20 in 1990 and $17 \mathrm{mbd}$ in the year 2000 .

This is a goal worth pursuing, and without underestimating the obstacles, we may be confident that these are realistic targets that can be attained.

\section{Experts' Recommendations on Coal}

$\mathbf{T}$ he International Energy Agency (IEA) Coal Industry Advisory Board (CIAB) ${ }^{1}$ has presented its first report to Energy Ministers of the 21 IEA nations. The Report contains recommendations to governments and industry for a Coal Action Programme to rapidly expand world coal production, trade and use.

The $\mathrm{CIAB}$ report concludes that current world coal growth is too slow to meet the goals of doubling world coal production and use by 1990 and tripling it by the year 2000.

Over the next twenty years, the major market for coal will be in electricity generation. The Board's assessment of potential suggests that tripling coal use by 2000 will require a tripling of current coal-fired generation capacity within the OECD, from today's 350 Gigawatt electric (GWe) level to $1100 \mathrm{GWe}$ by the end of the century. (One Gigawatt equals one billion watts).

Uncertainty about the future role of coal is constraining its ability to reduce oil use in the industrialized countries, even though it is clear that coal is an economically attractive option. The CIAB believos that this uncertainty can be reduced by firm and prompt government and industry action.

Among the report's recommendations to governments are that:

- OECD countries make specific commit-

(1) The CIAB was formed in April 1980, as a result of the commitment taken at the Tokyo Economic Summit in June 1979 which established a high priority among Western countries for shifting from oil to coal wherever possible. Its mandate is to provide practical advice on how to remove bottlenecks to doubling coal production and use by 1990 and tripling it by the year 2000. The CIAB brings together more than 30 high-level individuals from major coal related industries around the world. They include coal companies, electric utilities, steel, oil and manufacturing companies; and national coal and electric boards. ments to create conditions for increased coal-fired electricity generating capacity to be put in place and measures are needed to:

- allow oil and gas prices to adjust to world levels:

- prohibit the construction of new oil-fired utility boilers for baseload and, wherever possible, for intermediate power generation;

- encourage the planned conversion of existing oil-fired boilers to coal, for both utilities and large industrial users;

- coal producing and exporting countries adopt measures to permit an increase in

Tripling of coal production and use by the year 20 


\section{Focus on Africa}

and 1.5 per cent in low-income Asia and 2.0 per cent and 2.3 per cent for the totality of developing countries.

\section{The Challenge}

This situation is all the more deplorable because Sub-Saharan Africa may indeed be the world's remaining land of opportunity. Much of Africa is rich in mineral resources, some of which have yet to be discovered, let alone developed. It may have a fair amount of still-hidden oil and natural gas. It has the world's largest untapped potentials of hydro-electric energy. Eventually, if these natural physical resources are exploited sensibly, efficiently and equitably, they should bring benefits to Africans as well as supplies to the rest of the world. The interest in blocking the degradation of the continent's ecology is manifest. So what accounts for the lagging performance of low-income Africa?

\section{Agriculture} subject of the 1980 report by John P. Lewis, President of OECD's Development Assistance Committee (DAC) just published.

\section{The Urgency}

"On the basis of all the economic projections we have seen so far, Africa in the year 2000 will not be in the ditch it is in now. It will be in the bottom of a deep, black hole".

This harsh reading of the present economic indicators for Sub-Saharan Africa, by a senior African official of the United Nations Economic Commission for Africa, is widely shared ${ }^{1}$.

Today each person in the region has, on average, considerably less access to food than was the case ten years ago, and average dietary standards have fallen below nutritional requirements. Average food production per person has steadily declined since 1960.

During the 1970s Africa's annual population growth (2.7 per cent) was 14 per cent higher than the average for developing countries generally; during the 1980 s, when population growth in the rest of the developing world is projected to turn downward, it is expected to rise to 2.9 per cent.

During the 1970s the growth of per capita income in the low-income countries $^{2}$ of Sub-Saharan Africa averaged only 0.2 per cent annually compared with 1.1 per cent in the low-income countries of Asia and 2.9 per cent in developing countries generally. According to projections based on assumptions the World Bank regards as optimistic, per capita income in low-income Africa is expected to go up only 0.1 per cent annually between
1980 and 1985 and 1.1 per cent between 1986 and 1990, compared with growth rates respectively of 2.0 per cent and 2.6 per cent in low-income Asia and of 2.6 per cent and 3.3 per cent in developing countries generally. More conservative estimates have real incomes in the poorer African countries declining by 0.3 per cent annually between 1980 and 1985 , then edging barely positive - to 0.1 per cent between 1986 and 1990, compared with annual rates respectively of 1.1 per cent
Agriculture is at the core of these perverse dynamics. Access to export markets, trends in export prices, obstacles to more indigenous processing,

(1) Chicago Tribune, 3rd April 1980, article by Ray Moseley. The indicators referred to in this article are taken from the Organisation for African Union (OAU), the Economic Commission for Africa (ECA), the African Development Bank, the Food and Agricultural Organisation, the World Food Council and the International Fund for Agricultural Development.

(2) Defined by the World Bank as those countries except China having a 1978 GNP per person of US\$360 or below.

Today each person in the Sub-Saharan region has, on average, considerably less access to food than was the case ten years ago. Below: emergency feeding centre in Uganda.

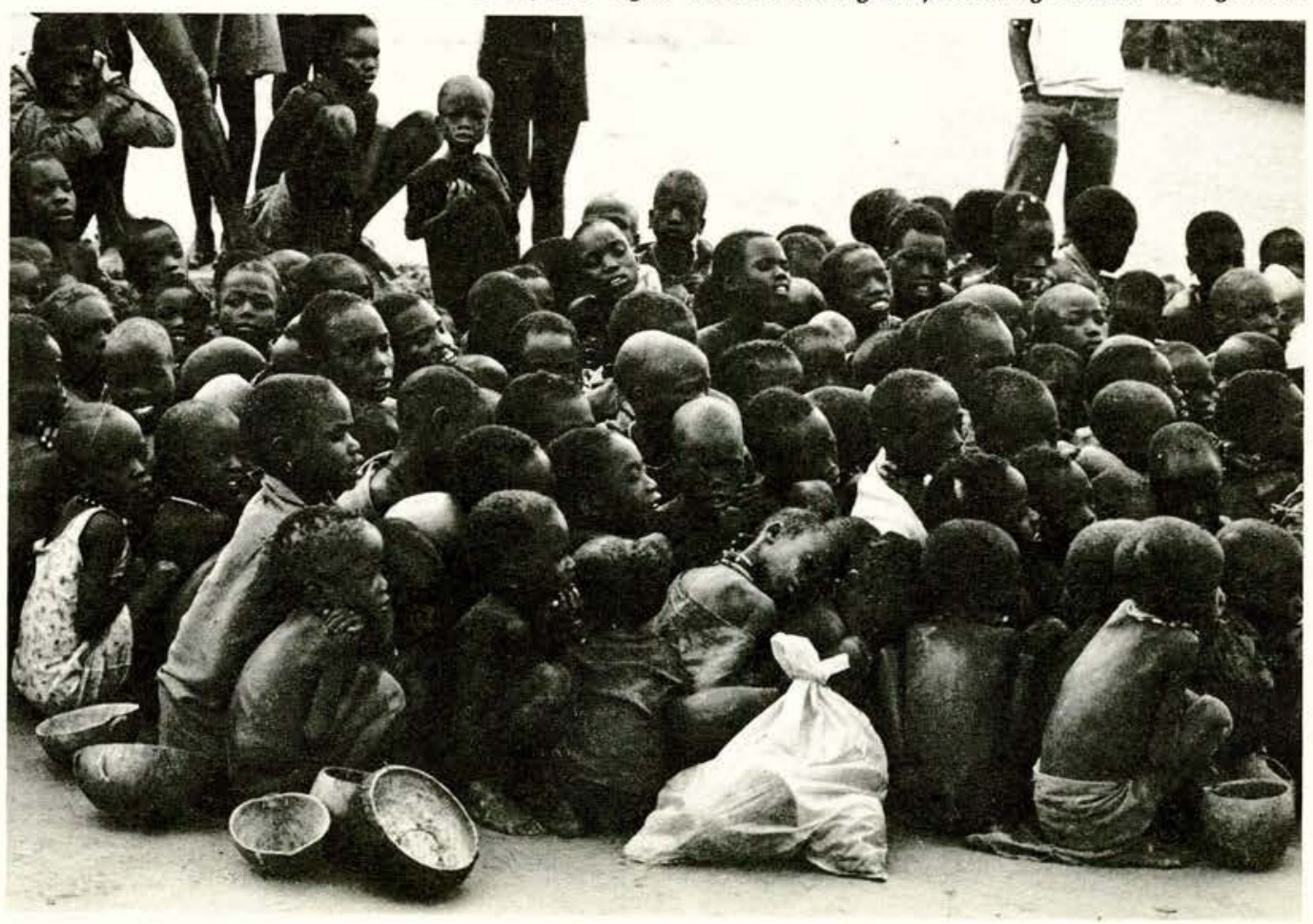




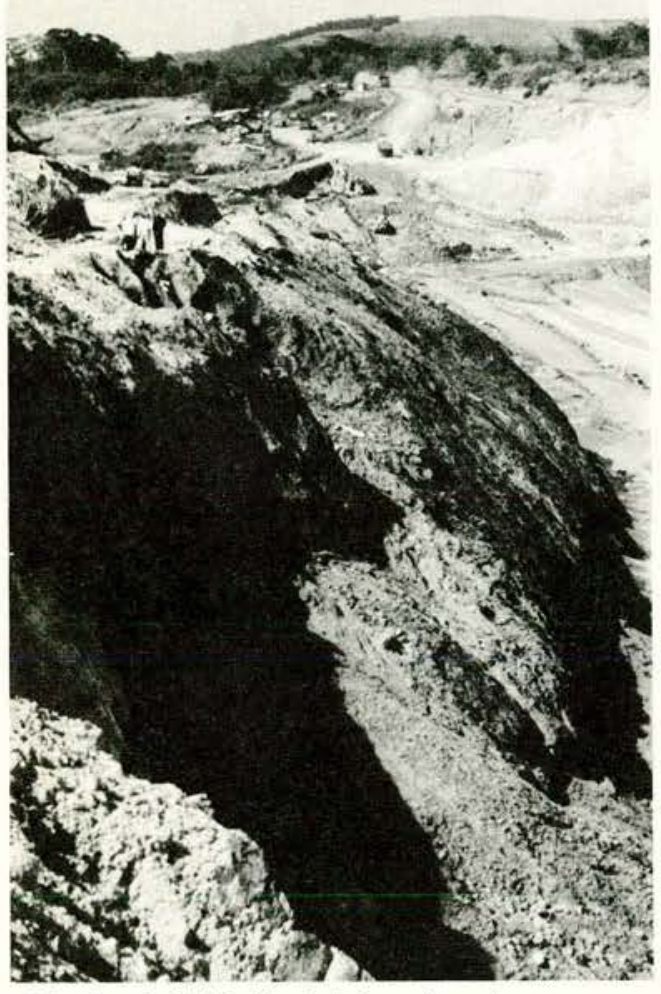

Much of Africa is rich in mineral resources. Above: uranium mine in Gabon.

aggravated balance of payments and structural adjustment needs, and so on, complicate this issue, but no acceleration strategy will get much of a purchase on the problem of mass poverty until the per capita outputs of the total rural labour force, including the under-employed, start climbing convincingly, thereby narrowing the bloated rural-urban income differentials and until low-income Africa's food output catches up with and substantially surpasses its population growth, thereby beginning to staunch the drain of foreign exchange into food imports.

Why has African agriculture been lagging so badly? Why, for example, has it not matched the slow, still fragile, but distinct momentum that agriculture has acquired in South Asia during the past ten to fifteen years, also under difficult conditions? There are many answers to these questions. In view of the different types of climate, African crop conditions may be more differentiated than in other developing regions. Much more work is needed on local adaptation and delivery of appropriate new-varietal technologies. The findings of the international crop research institute system need to be more effectively mediated at national and subregional level. Irrigation must not be neglected, of course, but there is a tendency to concentrate on it to the detriment of dry land farming. More generally there is great scope for improved water management - some of it on a large river system basis but a great deal at the smallproject and field levels. Epidemic diseases afflicting both people and animals need curbing. There is not the same need for classic land reforms as in other developing regions, but land-man relations as between private and communal holdings especially in the case of recently and/or still nomadic groups, are complex. Bureaucratic efforts to mobilise local initiatives have often been weak. So is the networking of the private market. In much of the area extension systems are thin and ineffective; there are gaps in input supplies; farm-to-market transport is lacking; there are gaps in marketing and storage systems; the parastatal organisations created to fill them or to pre-empt the field from the private sector are often cumbersome, inept and sometimes venal. In many countries government price and procurement policies have dampened farmers incentives.

This is almost a tiresomely familiar list. But though every one of these issues deserves urgent pursuit, one's general impression is not of a sector that stands in need of a whole new policy paradigm. Most of the issues are known, and so are reasonably reliable processes for generating solutions, piece-by-piece. What has been lacking, rather, have been sufficient implementation and, in particular, sufficient political and bureaucratic energy and grasp of the composite problem to build the partial answers into effective strategies.

\section{What Has Inhibited the Effectiveness of Investment?}

To understand the perverse dynamics that are at work, the cause must be identified: what underlying factors have slowed and impeded momentum along development paths that already are broadIy visible? Neither "under-investment" nor "external neglect" is a sufficient answer. The World Bank estimates that in 1978 land there was no particular peaking in that year) gross domestic investment of all sorts accounted for about 18 per cent of GNP in the low-income African countries. Almost surely, too little of this amount was allocated to agriculture; yet the striking thing, given the sluggishness of African performance, is that the investment rate was so high. In addition, while there has been variance among the individual African countries, for two decades average per capita ODA to low-income Africa has been comparatively high by international standards.

So the problem has not simply been under-investment in the aggregate, but the productivity of investment. What have been the main, systematic constraints that have inhibited the effectiveness of investments so far? Three factors weigh particularly heavily: unbridled population growth, inherited political complexities, and infrastructural gaps.

\section{The population explosion}

Although low-income Africa has the highest death rates among major regions, its rate of population growth surpassed

African crop conditions may be more differentiated than in other developing regions. Below: planting "gao" trees in Niger which may help to triple or quadruple millet and sorghum yields.

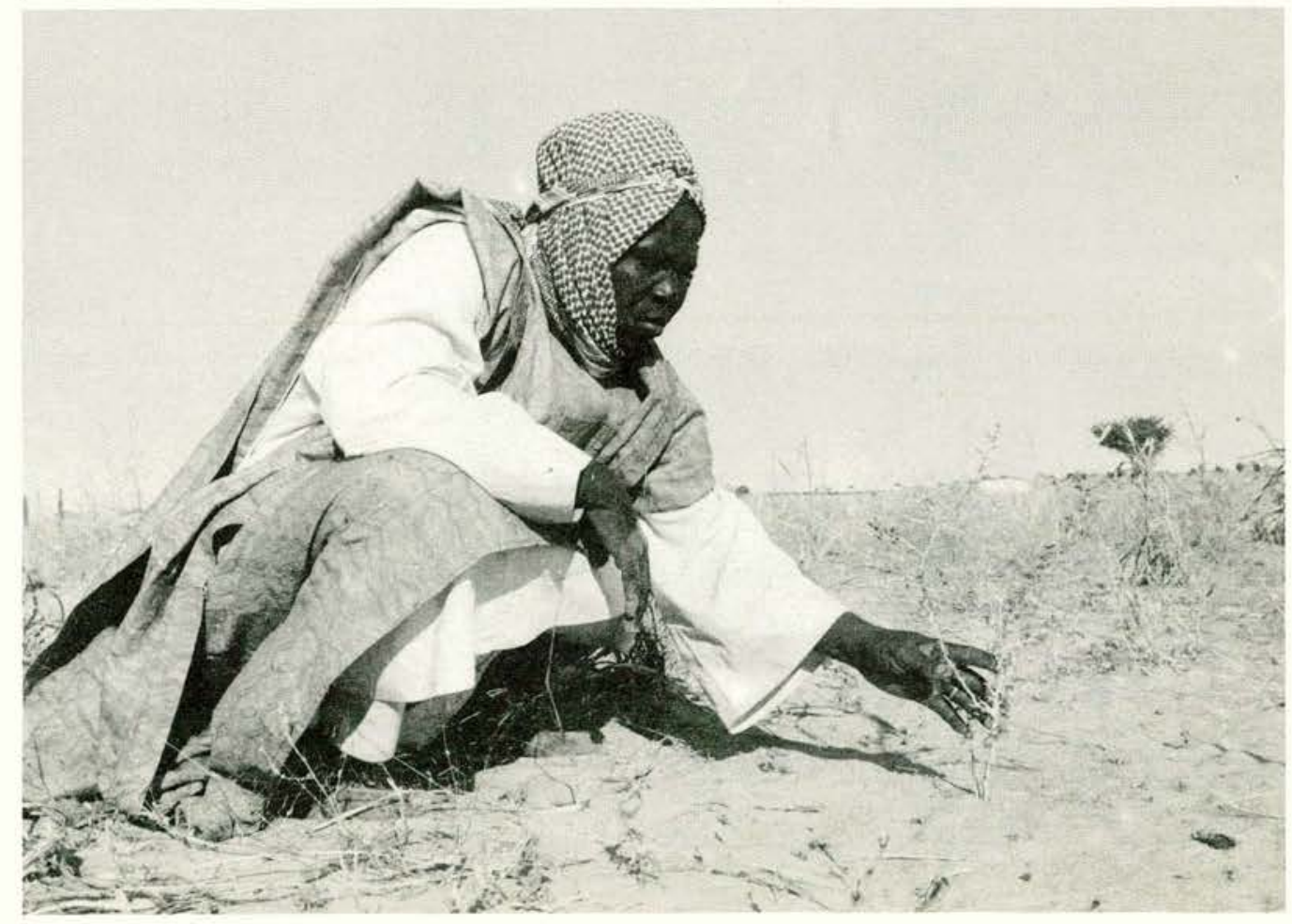




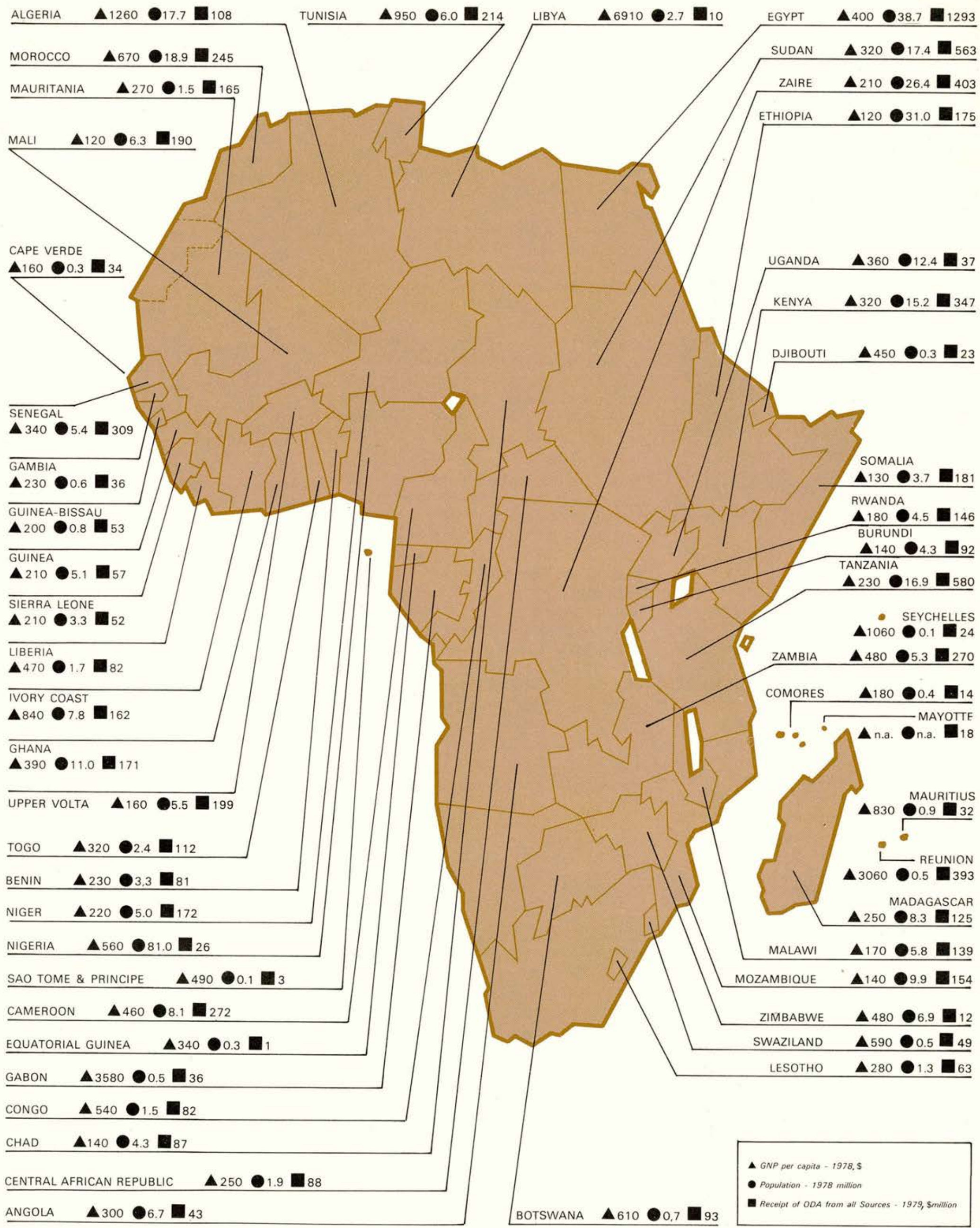



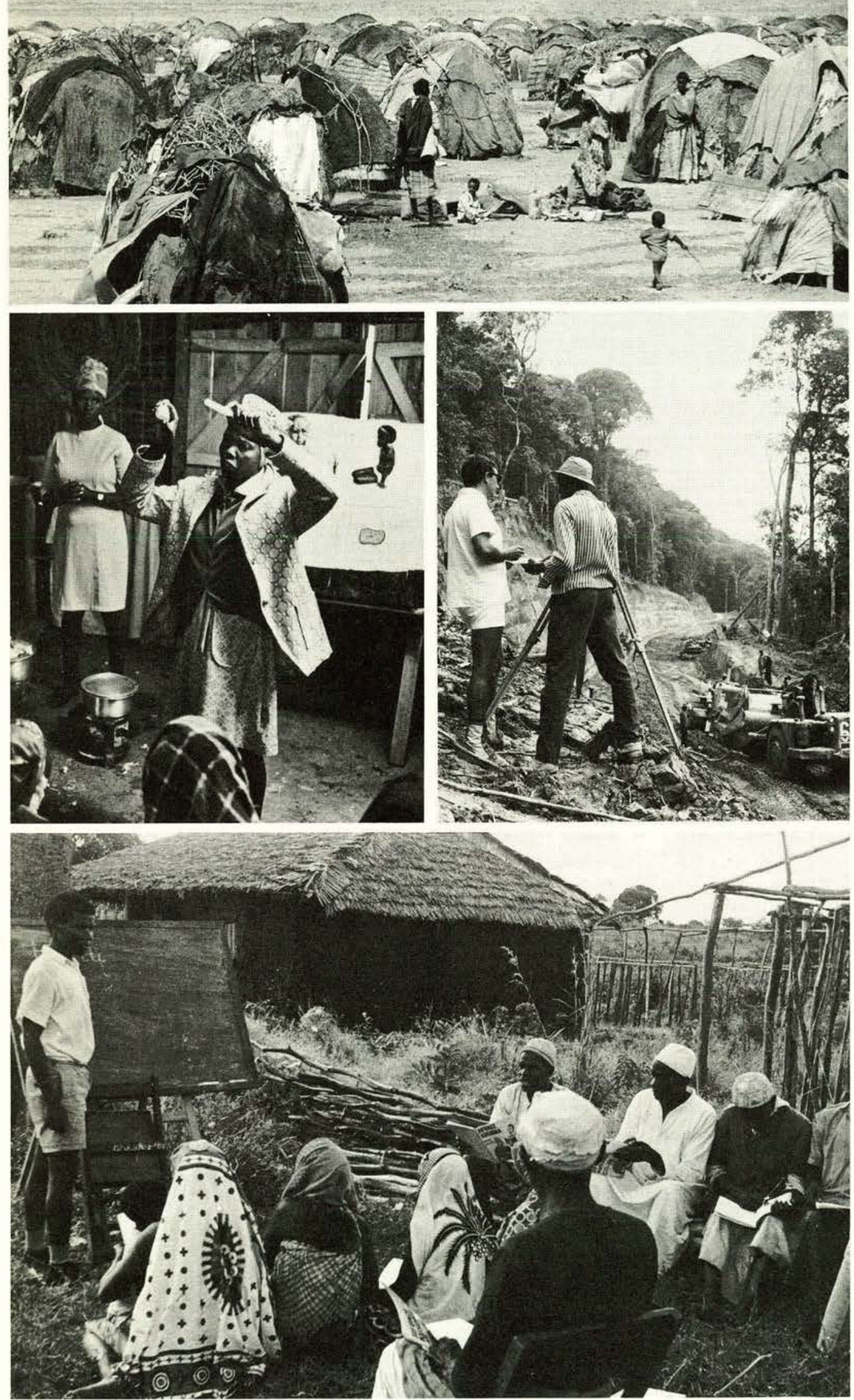

Unbridled population growth, inherited political complexities, and infrastructural gaps are three factors weighing heavily in the inhibition of investment effectiveness. (a) The effects of turbulence and political fragmentation are seen in refugee camps such as this one (Ethiopia). (b) In Kenya, family planning is combined with nutrition: as women learn better ways of feeding their families, they usually prove more receptive to birth-spacing ideas. (c) Road construction will permit Gabon to develop inaccessible hardwood forests. (d) To fight illiteracy - a major gap in human infrastructure - Tanzanian students are encouraged to teach their elders to read. that of developing countries generally during the 1970s. In the 1980s, with death rates declining faster than birth rates, Sub-Saharan Africa, including its lowincome countries, is the one region in which the growth rate promises to rise further. Obviously this is no reason to slow the attack on mortality. Such a proposition not only would be ethically monstrous; it would overlook the evident linkage between mortality and fertility: lowering the former, especially infant mortality, is clearly a powerful, even necessary means of reducing the latter.

While the average population density of rural areas is far less than in some other regions, notably in South Asia, this cannot camouflage the fact that high fertility is one of the pervasive retardants to lowincome Africa's development performance, in particular by slowing progress towards agricultural self-reliance.

Whereas the welfare gains that will flow from fertility reduction in Sub-Saharan Africa are particularly clear, no other major region still has so many governments which still are avowedly pro-natalist or so few promoting significant population restraint efforts. Latterly, moreover, most of the external actors have tended to tiptoe around the issue. The question of how to relax the fertility constraint on development during the balance of the century deserves a prominent place on any new agenda for the region.

\section{Political complexities}

The colonial experience left the new States with an intense jealousy of their sovereignty, a reluctance to intrude on the sovereign prerogatives of each other, and an allergy to external interference. It has also made for a degree of Pan-African solidarity which, properly directed, is a potential plus for development purposes.

Two other legacies of Africa's recent history may stand in the way of development. The first is political fragmentation. The combination of traditional Africa's tribal organisation and the boundary drawing done in European chancellories in the late 19th and early 20th centuries endowed africa with a remarkably large number of states -47 in all south of the Sahara. In 1978 only six were estimated to have populations in excess of $15 \mathrm{mil}$ lion, 26 numbered less than 5 million each, and 14 had populations of less than 1 million.

Secondly, history undoubtedly contributed to a high level of internal political turbulence and violence. It may be difficult to claim that African political instability has been exceptional, but it has been consistently high and widespread. And among its explanations are both the delayed start in political self-management and, in terms 
redeployment of internal economic activity needed to bring this about.

\section{A New Push Forward}

How can an immediately accelerated response to the problem of lagging lowincome African development begin to get translated into action? A programme for a new development: thrust in Africa would involve several strands of action.

\section{A monitoring system}

In terms of chronological priorities, the first need is at once to organise an adequate monitoring system to identify the emerging scale and comparative urgencies of needs for near-term assistance. This system would assist structural adjustments by formulating ad hoc responses to individual cases. The logical frames for response would be standing aid consortia or consultative groups or equivalent special agencies in each country (or groups of small and mini-countries) encountering balance of payments emergencies. Particular efforts should be made to encourage the OPEC donors to join these exercises.

It would give quick impetus to PanAfrican regional institutions if this nearterm monitoring could immediately be centred on them. But here one must be realistic: time is of the essence; much of the information and expertise required is concentrated, right now, in the IMF and the World Bank; and the quickness and adequacy of donor responses will be a function of the authority as well as the fullness of the financial analyses with which they are presented. The best formula, therefore, seems to be for the two Washington institutions to take the monitoring lead on what have been called low-income Africa's near-term macro problems. However, if the strategy of building up the Pan-African regional institutions is correct, then they should be associated with this immediate exercise in a far fuller, more explicit way than would have been the inclination heretofore, thereby helping prepare them to "take over" the next time such a set of balance of payments emergencies befall.

\section{Skilled manpower}

This is the second item on the agenda for a push: the skilled manpower bottleneck should be the chief medium and long term target for a regionallycentred acceleration programme. It is a subject on which the regional organisations have already done fairly impressive homework and about which they have organised commitments by their own members. If the outside actors are ready to join a low-income African push, this is an area in which they can quickly demonstrate their willingness to channel incremental efforts to and through the Pan-African regional organisations.

\section{Infrastructure}

In the third place, the whole panoply of sectoral and cross-sectoral studies of infrastructural gaps at both the national and regional levels needs to be taken up on an urgent basis. The studies regime

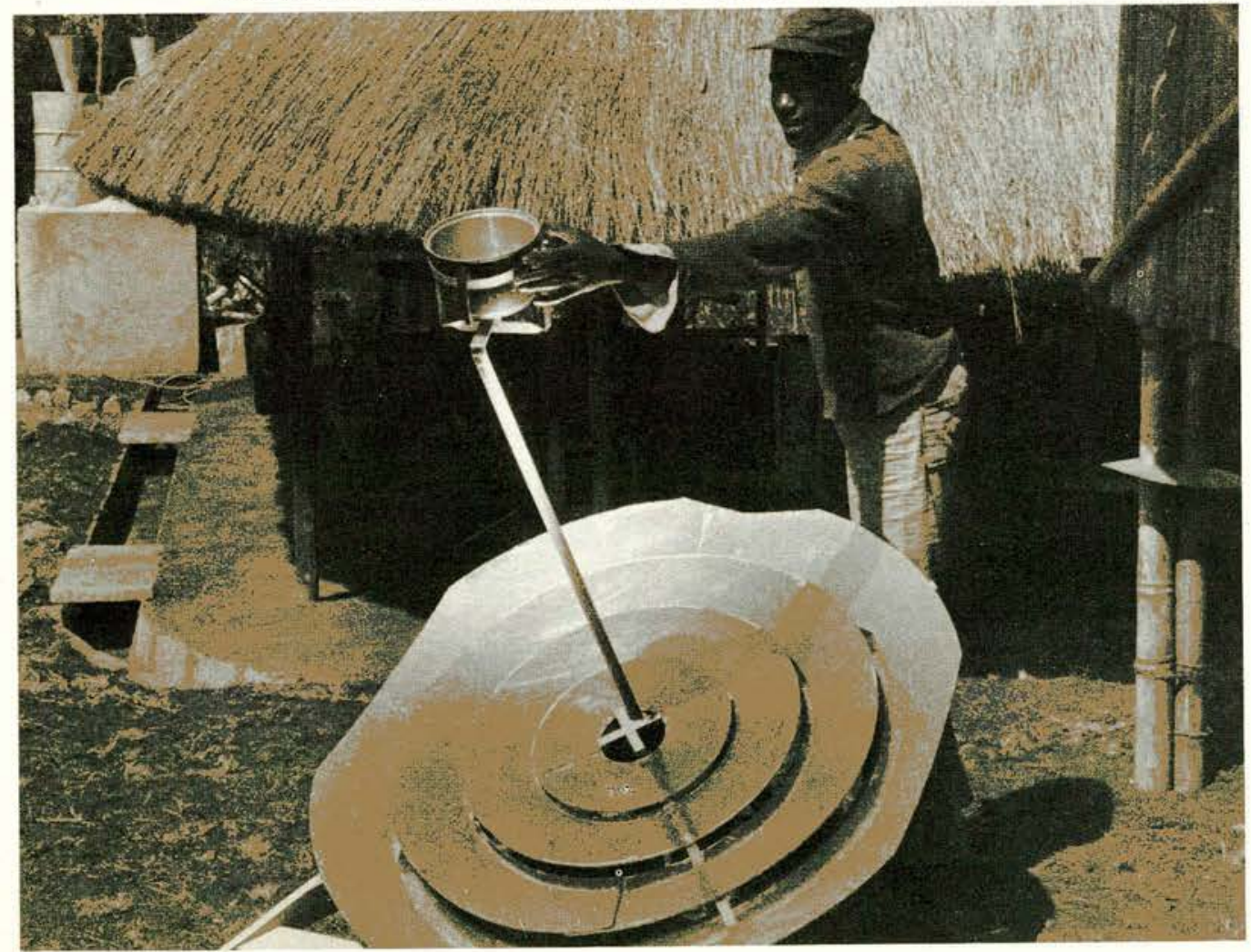

needs to be African-led but to command effective external participation. Most of it should consist of country studies but with the guidelines for these components and the promotion of transnational components coming from the regional centres. The studies regime must be freshly and comprehensively designed, with the purpose not of rejecting good components already in hand but of evaluating them, of filling in the gaps, and in particular of testing the internal consistency of different combinations of activities within alternative resource availabilities. Finally the whole regime must be time-bound, so that one will be able to begin drawing from it initial guidelines for major allocations of incremental resources within, say, two years.

During the past year, discussions in and around DAC have touched on a variety of substantive matters that are plainly central to low-income Africa's development prospects - for example, the linkages among water, crops, research, environment and energy; or again, the way the issue of firewood ramifies into forestry, agriculture, energy, nutrition and the condition of rural women; or still further, the symbiosis among employment, road building, and a constructive use of the food aid that would seem to be available to much of the region during the next decade - if only the management and maintenance (skilled human resources) constraints can be eased. These are precisely the kinds of subjects that a fresh, joint and comprehensive regime of actionoriented studies should address.

\section{Subregional units}

The kind of regionally-centred initiative herein contemplated would not and should not operate only at two levels one at national, the other region-wide. There are many opportunities for subregional groups of contiguous countries to batch themselves together constructively for selected development purposes. The present discussion has been dilinquent in the paucity of its references to the CILSS - Club du Sahel effort. On balance, the latter has been remarkably effective thus far and the present scenario, far from implying its abandonment, would imply its replication. Donors are not unaware of or disinterested in such possibilities. But they find it almost impossible, on their own initiatives, to reproduce the Sahelian case, and they have observed that most other special-purpose subregional groups in Africa have not, because of the political turbulence, exhibited great staying power. In essence the point here reduces to a reminder of one of the aspirations one would have for an enhancement of the Pan-African regional organisations: to identify and promote subregional 


\section{New OECD Publications}

\section{"OECD Economic Surveys". 1981 Series}

Detailed annual surveys of trends and prospects for each OECD country.

SWITZERLAND (October 1980)

(10 8126 1) ISBN 926412108072 pages

ICELAND (November 1980)

(1031 171) ISBN 926412135872 pages

Each issue
ISSN 03766438

Subscription

F14.00 £1.60 US\$3.50

$F 240,00 £ 26.60$ US $\$ 60.00$

\section{OECD ECONOMIC OUTLOOK No. 28}

(December 1980)

(1280281) ISBN 9264121404

156 pages

ISSN 03043274

Subscription (2 issues - July and December 1981)

F70,00 f 7.80 US $\$ 17.50$

CONTROLS ON INTERNATIONAL CAPITAL MOVEMENTS: Experience with controls on international portfolio operations in shares and bonds (January 1981)

Reviews the various methods of control on international portfolio operations and the extent of their contributions to economic policy objectives of Member countries. The main findings of this study suggest that portfolio operations in shares and bonds are relatively free in the OECD area, compared to the past. The effectiveness of controls with respect to their objectives is assessed, and some lessons are drawn from the review of experience that can be of assistance to Member countries, and to the evaluation of their policies.

(21 8007 1) ISBN 9264121382

64 pages

$F 28,00$ £2.80 US\$7

THE TAX/BENEFIT POSITION OF SELECTED INCOME GROUPS IN OECD MEMBER COUNTRIES, 1974-1979 (152 pages), and THE 1979 TAX/BENEFIT POSITION OF A TYPICAL WORKER IN OECD MEMBER COUNTRIES (52 pages, bilingual)

(January 1981)

(23 8002 1) ISBN 9264121323

F76.00 $₹ 7.60$ US\$19.00

COSTS AND MARGINS IN BANKING. An International Survey (June 1980)

(2180031) ISBN 9264120645

308 pages

F98,00 f 10.80 US $\$ 24.50$

\section{Public Management Series:}

1 - STRATEGIES FOR CHANGE AND REFORM IN PUBLIC MANAGEMENT

(September 1980)

142800111 ISBN 9264121218

244 pages

F64.00 £7.10 US\$16.00

REGIONAL POLICIES IN THE UNITED STATES (December 1980) "Document"Series

A survey of United States policies to deal with economic development problems arising in various parts of the Nation. It has been prepared by experts from other OECD Member countries who comment on United States practices in the light of experiences in their own countries and draw attention to points where United States' experience could be of value to other countries.

(70 8001 1) ISBN 9264120866

100 pages

$F 22.00 \quad £ 2.40$ US $\$ 5.50$

REGIONAL POLICIES IN CANADA

"Document" Series (August 1980)

(70 80021 1) ISBN 9264121048

84 pages

F 20.00 £ 2.20 US $\$ 5.00$
THE UTILISATION OF THE SOCIAL SCIENCES IN POLICY MAKING IN THE UNITED STATES. Case Studies (December 1980) "Document" Series

Nine studies on the utilisation of the social sciences by the US Government, in the mid70's, in areas such as housing, labour, environment, health, income distribution, regional policy, justice.

1928003 1) ISBN 9264121285 394 pages

F80,00 $£ 8.90$ US $\$ 20.00$

ICCP Series No. 4 - HANDBOOK OF INFORMATION COMPUTER AND COMMUNICATIONS ACTIVITIES OF MAJOR INTERNATIONAL ORGANISATIONS (August 1980)

(9380011) ISBN 926412035 1

240 pages

$F 58,00$ £ 6.40 US\$14.50

WOMEN AND EMPLOYMENT. Policies for Equal Opportunities (December 1980)

Contains the acts of the High Level Conference on the Employment of Women - April 1980 which agreed on a Declaration concerning the aims and policies of Member countries towards equality of employment opportunity and equal pay for men and women.

(8180041) ISBN 9264121366

172 pages

$F 38,00$ £ 3.80 US $\$ 9.50$

YOUTH UNEMPLOYMENT. The Causes and the Consequences (December 1980)

Youth unemployment has become a major problem in most OECD countries in recent years. While many policy measures have been implemented to improve the employment prospects of young people, the overall situation has clearly not improved

(81 8005 1) ISBN 9264121374

134 pages

$F 32,00$ £ 3.20 US\$8.00

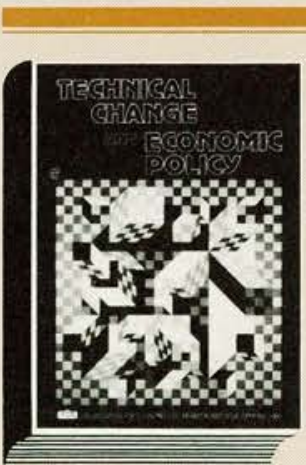

TECHNICAL CHANGE AND ECONOMIC POLICY. Science and

Technology in the New Economic and Social Context

August $1980,120 \mathrm{p}$.

f5.60 US\$12.50 F50

The $1 O E C D$

committee marshals

impressive evidence which gives the lie to the cynical view that research and development is irrelevan to industrial innovation" (Nature, 10 July, 1980)

a timely, œcumenical view of what is wrong economically and what to do about it". (Science,

September, 1980)

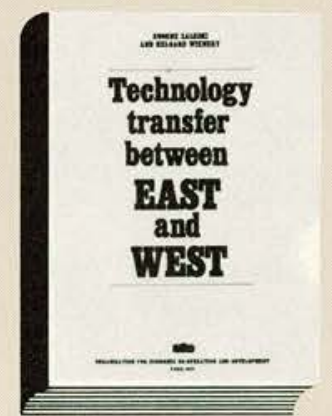

TECHNOLOGY

TRANSFER

BETWEEN EAST

AND WEST,

by Eugene Zaleski and Helgard Wienert October 1980, 436 p. f22 US\$50 F 200

The comprehensive study published by the Organisation for Economic Co-operation and Development, contains some disturbing implications for the US and other Western nations that trade, with the Soviet bloc." (The Wall Street Journal, 10 October 1980)
DEVELOPMENT CO-OPERATION. Efforts and Policies of the Members of the Development Assistance Committee. 1980 REVIEW (December 1980)

Annual report of the Chairman of the Development Assistance Committee containing aid statistics, reflecting recent Committee work and featuring the Chairman's views on the state of the North-South dialogue, the problems of low-income Africa and the question of the effectiveness of aid.

4338001 1) ISBN 926412141 .

270 pages

$F 76.00$ £ 7.60 US\$19.00

\section{"Development Centre Studies"}

MORTALITY IN DEVELOPING COUNTRIES. DATA BANK, by Julien Condé, Michèle Fleury-Brousse, Dominique Waltisperger (with the collaboration of the Department of Demography of the Catholic University of Louvain and the United Nations Population Division, New York).

Volume I: POPULATION STRUCTURES. Volume II: RAW DATA: DEATHS, MORTALITY RATES AND LIFE TABLES $(666$ pages, bilingual)

Volume III: EVALUATION. Volume IV: ADJUSTMENTS (November 1980)

Evaluates the regularity of the population distributions and the coverage rates of deaths through different mathematical techniques, and adjusts these data.

(41 80053 ) ISBN 9262020977608 pages, bilingual

$F 340,00 \quad £ 37.80$ US\$85.00

Volume VNolume VI: NEW MODEL LIFE TABLES FOR USE IN DEVELOPING COUNTRIES, by Rémy Clairin, Julien Condé, Michèle Fleury-Brousse, Dominique Waltisperger, Guillaume Wunsch (November 1980)

Provides models with single and several double entries and describes different methods utilised to derive these models.

41300611 ISBN $926412120 \times$

550 pages

$F 120,00 £ 13.00$ US\$30.00

INTER-REGIONAL CO-OPERATION IN THE SOCIAL SCIENCES FOR DEVELOPMENT Liaison Bulletin No. 5 (July 1980)

Papers and Proceedings of the Second InterRegional Meeting on Development Research, Communication and Training, which took place in Bogota in June 1979. General theme: Interdependence and Development. Three topics of "common interest" were discussed:

a) Rural development, agriculture and food;

b) Regional Integration and Co-operation

c) Transnational corporations.

(40 8002 1) ISBN 9264120882

200 pages

$F 38,00$ f 4.20 US\$9.50

REGISTER OF DEVELOPMENT RESEARCH PROJECTS IN ASIA. LIAISON BULLETIN BETWEEN DEVELOPMENT RESEARCH AND TRAINING INSTITUTES. No. 4 (June 1980) $(4080013)$ ISBN 9264020969

352 pages, bilingual

$770,00=7.80$ US\$17.50

EVALUATING SOCIAL PROJECTS IN DEVELOPING COUNTRIES. by Howard E. Freeman, Peter H. Rossi, Sonia H. Wright (October 1980) "Document" Series (4180041) ISBN 9264120408 240 pages

F $36,00 £ 4,00$ US $\$ 9.00$ 
MANAGING INFORMATION FOR RURAL DEVELOPMENT PROJECTS bY $\mathrm{N}$. Imboden "Document" Series (August 1980)

(41 8003 1) ISBN 9264120394

$F 26,00$ \&. 2.90 US $\$ 6.50$

THE STRUGGLE FOR BASIC NEEDS IN NEPAL (August 1980)

(41 8007 1) ISBN 9264121013

104 pages

F26.00 £ 2.90 US\$6.50

SCHOOL AND COMMUNITY Vol. ॥

"Document" Series (August 1980)

(9680011) ISBN 9264120823

132 pages

$F 32,00 \quad £ 3.60$ US $\$ 8.00$

\section{NOISE ABATEMENT POLICIES}

7th-9th May 1980 (July 1980)

(978005 1) ISBN $926412084 X$

392 pages ...................F 64,00 £ 7.00 US $\$ 16.00$

CHEMICAL TRENDS IN WILDLIFE - An International Co-operative Study (December 1980) "Document" Series

Describes the methodology and results of a 4year international research effort which sought to develop wildlife sampling and analysis techniques to monitor trends in chemical contamination of the environment.

(978006 1) ISBN 9264121056

250 pages

F28,00 £3.10 US\$7.00

TOURISM POLICY AND INTERNATIONAL TOURISM IN OECD MEMBER COUNTRIES, 1980 (October 1980)

(78 8001 1) ISBN 9264121234

192 pages F7S,O0 \&8.70 US\$19.50

"Document" Series

(248002 1) ISBN 9264120777

44 pages

F18,00 £2.00 US $\$ 4.50$

A GROUP STRATEGY FOR ENERGY RESEARCH, DEVELOPMENT AND DEMONSTRATION. IEA OIL IMPORTS (October 1980) The result of a five year study and the first attempt by a group of nations to focus on which new technologies could contribute most to IEA energy needs of the next 40 years. Compares two paths for energy RD \& D activities to the year 2000 .

161800511 ISBN 9264121242

93 pages

$F 32.00 £ 3.60$ US $\$ 8.00$

BOREHOLE AND SHAFT PLUGGING Proceedings, Columbus, United States, May 1980. Workshop organised jointly by the OECD Nuclear Energy Agency and the United States Department of Energy (December 1980)

The safety of radioactive waste disposal in geological formations may be partially dependent on the successful plugging of all penetrations connecting the disposal zones with the biosphere. These proceedings represent a review of research and development in this important area.

(6680093) ISBN 9264021140 , bilingual

436 pages

F12000 11200 US\$30.00

\section{"Road Research"}

URBAN PUBLIC TRANSPORT: EVALUATION OF PERFORMANCE

The need to evaluate the performance of urban public transport systems has become acute because of steadily rising operation costs and escalating deficits. The study of evaluation methods and performance indicators is designed to help decision-makers and public transport managers to assess the options and strategies for urban transport operation and investment

(77 8004 1) ISBN 9264121277

80 pages

$F 22,00 £ 2.40$ US\$5.50
TRANSPORT AND THE CHALLENGE OF STRUCTURAL CHANGE. Eighth International Symposium on Theory and Practice in Transport Economics, Istanbul, 24th-28th September 1979. Introductory Reports and Summary of the Discussion (September 1980)

(75 8004 1) ISBN 9282110613

540 pages

$F 80,00$ £8.90 US\$20.00

RESEARCH ON TRANSPORT ECONOMICS

Vol. XIII No. 1 - May 1980 (September 1980)

$(7480013)$ ISSN 0304-3320 130 pages, bilingual Subscription (Two issues yearly) .....F 180,00 f20.00 US $\$ 45.00$

RESOLUTIONS OF THE COUNCIL OF MINISTERS OF TRANSPORT AND REPORTS APPROVED IN 1979. VOlume II. Belgrade, 30th-31st May 1979. Paris, 23rd November 1979 (September 1980)

(75 8005 1) ISBN 928211052

246 pages

F88,00 $\$ 9.80$ US\$22.00

SCOPE FOR RAILWAY TRANSPORT IN URBAN AREAS. 47th Round Table ECMT (August 1980)

Case studies of transport systems in 14 European cities; traffic; organisation of transport undertakings; financing of investment and maintenance; financial situation; arguments in favour of rapid transit railway services: summary report.

1758006 1) ISBN $928211063 x$

376 pages

$F 80,00 £ 8.90$ US\$20.00

TRANSFERS THROUGH THE TRANSPORT SECTOR: EVALUATION OF RE-DISTRIBUTION EFFECTS. 48th Round Table ECMT (September 1980)

(75 8007 1) ISBN 9282110648

96 pages

F24,00 £2.70 US $\$ 6.00$

MARITIME TRANSPORT, 1979

(September 1980)

(76 3001 1) ISBN 9264121226

152 pages

$F 42,00 £ 4.70$ US\$10.50

REVIEW OF FISHERIES IN OECD MEMBER

COUNTRIES, 1979 (September 1980)

(538002 1) ISBN $926412103 X$

256 pages

F 48,00 ₹5.30 US\$12.00

NUCLEAR LAW BULLETIN

No. 25 - June 1980 (August 1980)

No. 26 - December 1980 (January 1981)

1678026 1) ISSN 0304-341X60 pages

(67 8025 1) ISSN 0304-342896 pages (Two issues yearly) Subscription

F50,00 $\mathrm{f} 5.60$ US $\$ 12.50$

\section{Statistics}

PUBLISHED OFFICIAL SOURCES OF FINANCIAL STATISTICS (September 1980)

"Document" Series

(213006 3) ISBN 9264020950

132 pages, bilingual .............F F4.00 £4.90 US\$11.00

NATIONAL ACCOUNTS OF OECD COUNTRIES 1961-1978. Vol. II. Detailed Tables (August 1980)

(308003 3) ISBN 9264020942

286 pages, bilingual

$F 72,00$ £8.00 US\$18.00

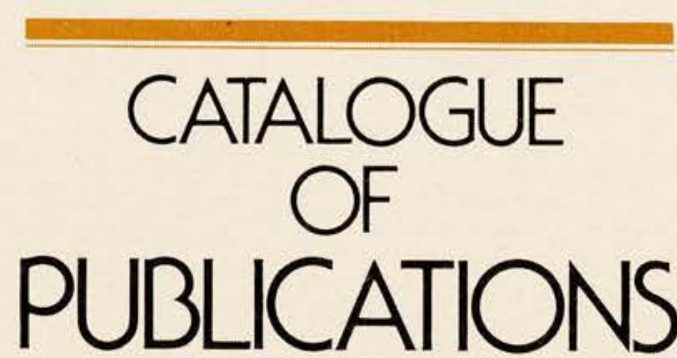

Free of charge
QUARTERLY NATIONAL

BULLETIN 1980/II (July 1980)

86 pages, bilingual

Subscription ISSN 0304-3738 .... F50.00 £5.60 US\$12.50

QUARTERLY NATIONAL ACCOUNTS BULLETIN, 1980/III (November 1980)

(360000 3) ISSN 0304373882 pages, bilingual

Subscription

$F 50.00$ ₹5.60 US\$12.50

MAIN ECONOMIC INDICATORS (monthly) bilingual

Each issue

$F 20,00 € 2.20$ US $\$ 5.00$

Subscription

F200,00 f

MAIN ECONOMIC INDICATORS. Historical Statistics. 1960-1979 (September 1980)

(3180203) ISBN 9264021108

638 pages, bilingual

F110.00 $\mathrm{f} 12.20$ US $\$ 27.50$

REVENUE STATISTICS OF OECD MEMBER COUNTRIES, 1965-1979 (October 1980)

(2380013) ISBN 9264021116

228 pages, bilingual

F70,00 $₹ 7.80$ US $\$ 17.50$

INDICATORS OF INDUSTRIAL

ACTIVITY 1980 || (August 1980)

(37 8002 3) 122 pages, bilingual

INDICATORS OF INDUSTRIAL

ACTIVITY 1980 IV

This publication provides an overall view of short-term economic developments in different industries for all OECD Member countries. It presents indices of output, new orders, unfilled orders, prices and employment. The statistics are classified by major division, division, major group and group of economic activity following the International Standard Industrial Classification (ISIC). Various qualitative data from business tendency surveys carried out in OECD Member countries are also included.

378004 3), bilingual

120 pages

$F 28.00 € 3.10$ US\$7.00

Subscription 4 issues)

F100.00 f11.00 US\$25.00

LABOUR FORCE STATISTICS, 1967-1978 (July 1980)

(30 30023 ) ISBN 9264020926

440 pages, bilingua

F85,00 $₹ 9.40$ US $\$ 21.25$

LABOUR FORCE STATISTICS. Quarterly Supplement III - August 1980 (October 1980) 72 pages, bilingual

350000 3) ISSN 03043312

Subscription

$F 50,00 \quad £ 54.60$ US\$12.50

PULP AND PAPER. Quarterly Statistics 1980/2 (November 1980)

56 pages, bilingua

$(7380023)$ ISSN $0335377 X$

Each issue

$F 18.00 \quad £ 2.00$ US $\$ 4.50$ Subscription

NTERNATIONAL STANDARDISATION OF FRUIT AND VEGETABLES: GARLIC (Revision) September 1980)

518007 3) ISBN 9264020985

50 pages, bilingual

$F 48,00$ £5.30 US\$12.00

INTERNATIONAL STANDARDISATION OF FRUIT AND VEGETABLES: CITRUS FRUIT (November 1980) Revision

$(518009$ 3) ISBN 9264021124

108 pages, bilingual

$F 70.00 € 7.00$ US\$17.50

MILK, MILK PRODUCTS AND EGG BALANCES IN OECD MEMBER COUNTRIES 1973-1978 - May 1980 (June 1980) "Document" Series

518006 3) ISBN 9264020934

14 pages, bilingual

F46,00 $₹ 5.00$ US\$11.50

FINANCIAL MARKET TRENDS $N^{\circ}$ 16: THE USE OF NATIONAL CURRENCIES FOR EXTERNAL BOND ISSUES (November 1980) (27 8004 i)

112 pages

ISSN $0378651 \times$ ( 3 issues)

F28,00 £ 3.10 US\$7.00

Subscription

$F 80,00 € 8.90$ US\$20.00 


\section{ARGENTINA}

Carlos Hirsch S.R.L.,

Florida $165,4^{\circ}$ Piso,

(Galeria Guemes) 1333 Buenos Aires Tel. 33.1787.2391 Y 30.7122

AUSTRALIA

Australia and New Zealand Book Co. Pty. Ltd.,

10, Aquatic Drive, French Forest, 2086

(P.O.B. 459) Brookvale, 2100 Tel, 452.44.11

\section{AUSTRIA}

OECD Publications and Information Center,

4 Simrockstrasse,

5300 Bonn (Germany)

Tel. 21.60 .46

Local Agent:

Gerold \& Co., Graben 31, Wien 1

Tel. 52.22 .35

BELGIUM

LCLS,

35 , avenue de Stalingrad

1000 Bruxelles

Tel. 02.512.89.74

BRAZIL

Mestre Jou S.A.,

Rua Guaipá 518, Caixa Postal 24090 ,

05089 Sao Paulo 10

Rua Senador Dantas 19 s/205-6

Rio de Janeiro - G.B.

Tel. 261.1920

\section{CANADA}

Renouf Publishing Company Limited,

$2182 \mathrm{St}$. Catherine Street West,

Montreal, Quebec $\mathrm{H} 3 \mathrm{H} 1 \mathrm{M} 7$

Tel. (514) 937.3519

522 West Hasting

Vancouver, B.C. V6B 1 L6

Tel. (604) 687.3320

\section{DENMARK}

Munkgaard Export and Subscription Service

35, Nørre Søgade, DK-1370 København K Tel. (01) 12.85 .70

FINLAND

Akateeminen Kirjakauppa,

Keskuskatu 1, 00100 Helsinki 10

Tel. 65.11 .22

FRANCE

Bureau des Publications de l'OCDE

2 rue André-Pascal, F75775 Paris Cedex 16.

Principal correspondant :

Tel. (1) 524.81 .67

Librairie de l'Université,

13602 Aix-en-Provence. Tel. (42) 26.18.08

GERMANY

OECD Publications and Information Centre,

4 Simrockstrasse,

5300 Bonn

Tel. 21.60 .46

GREECE

Librairie Kauffmann,

28 rue du Stade, Athens 132.

Tel. 322.21 .60

HONG KONG

Government Information Services,

Sales and Publications Office,

Baskerville House, 2nd floor,

13 Duddell Street, Central.

Tel. 5.214375

\section{ICELAND}

Snæbjörn Jónsson \& Co., h.f.,

Hafnarstræti 4 \& 9

P.O.B. 1131 - Reykjavik.

Tel. $13133 / 14281 / 11936$

INDIA

Oxford Book and Stationery Co.,

Scindia House, New Delhi I.

Tel. 45896

17 Park St., Calcutta.

Tel. 240832
INDONESIA

PDIN LIP, P.O. Box 3065/JKT.Jakarta.

Tel. 583467

IRELAND

TDC Publishers - Library Suppliers

12 North Frederick Street, Dublin 1

Tel. 744835-749677

ITALY

Libreria Commissionaria Sansoni,

Via Lamarmora 45, 50121 Firenze

Tel. $579751 / 2 / 3$

Via Bartolini 29, 20155 Milano. Tel. 365083

Sub-depositari

Editrice e Libreria Herder,

Piazza Montecitorio 120, 00186 Roma

Libreria Hoepli,

Tel. 674628

Via Hoepli 5, 20121 Milano.

Tel. 865446

Libreria Lattes,

Via Garibaldi 3, 10122 Torino. Tel. 519274

La diffusione delle edizioni OCSE è inoltre assicurata dalle migliori librerie nelle cíttà più importanti.

JAPAN

OECD Publications and Information Center,

Landic Akasaka, 2-3-4 Akasaka,

Minato-ku, Tokyo 107.

Tel. 586.2016

\section{KOREA}

Pan Korea Book Corporation

P.O.Box No. 101 Kwangwhamun, Seoul. Tel. 72.7369

\section{LEBANON}

Documenta Scientifica/Redico,

Edison Building, Bliss St.,

P.O.B. 5641, Beirut. Tel. 354429-344425

MALAYSIA and SINGAPORE

University of Malaya Co-operative Bookshop Ltd.,

P.O.Box 1127, Jalan Pantai Baru,

Kuala Lumpur. Tel. 51425, 54058, 54361

NETHERLANDS

Staatsuitgeverij

Verzendboekhandel

Chr. Plantijnstraat

'S-Gravenhage.

Voor bestelligen.

Tel. 070-789911

NEW ZEALAND

Publications Section,

Government Printing Office,

Wellington: Walter Street. Tel. 847.679

Mulgrave Street, Private Bag. Tel. 737.320

World Trade Centre, Cubacade, Cuba Street.

Tel. 849.572

Auckland: Hannafort Burton Building,

Rutland Street, Private Bag. Tel. 32.919

Christchurch: 159 Hereford Street, Private

Bag Tel. 797.142

Hamilton: Alexandra Street, P.O.Box 857.

Tel. 80.103

Dunedin: T \& G Building, Princes Street,

P.O.Box $1104 \quad$ Tel. 778.294

NORWAY

J.G. Tanum A/S,

P.O.Box 1177 Sentrum, Oslo 1

Tel. (02) 801260

PAKISTAN

Mirza Book Agency

65 Shahrah Quaid-E-Azam, Lahore 3.

Tel. 66839

PHILIPPINES

National Book Store, Inc.

Library Services Division, P.O. Box 1934

Manila,

Tel. Nos. 49.43 .06 to $09,40.53 .45,49.45 .12$
PORTUGAL

Livraria Portugal,

Rua do Carmo 70-74, 117 Lisboa Codex.

Tel. $360582 / 3$

SPAIN

Mundi-Prensa Libros, S.A.,

Castelló 37, Apartado 1223, Madrid 1.

Libreria Bastinos de José Bosch,

Tel. $275.46 .55 / 276.02 .53$

Pelayo 52, Barcelona 1.

Tel. 222.06 .00

SWEDEN

AB CE Fritzes Kungl. Hovbokhandel,

Box 16356 , S 10327 STH

Regeringsgatan 12 ,

DS Stockholm.

Tel. $08 / 23.89 .00$

SWITZERLAND

OECD Publications and Information Center,

4 Simrockstrasse,

5300 Bonn (Germany).

Tel. 21.60 .46

Local Agents

Librarie Payot,

6 rue Grenus, 1211 Genève 11

Tel. 022-31.89.50

Freihofer A.G.

Weinbergerstrasse 109

8006 Zürich

Tel. (01) 362.42.82

TAIWAN

National Book Company,

84-5 Sing Sung Rd., Sec. 3,

Taipei 107

Tel. 321.0698

THAILAND

Suksit Siam Co., Ltd.,

1715 Rama IV Rd.

Samyam Bangkok 5.

Tel. 2511630

UNITED KINGDOM and

CROWN COLONIES

H.M. Stationery Office,

P.O.B. 569, London SE1 9NH Tel. (01) 928.6977, Ext. 410 or

49 High Holborn

London WC1V 6HB (personal callers)

Branches at: Belfast, Birmingham,

Bristol, Cardiff, Edinburgh, Manchester.

UNITED STATES

OECD Publications and Information Center,

Suite 1207, 1750 Pennsylvania Ave., N.W.,

Washington, D.C. 20006

Tel. (202) 724.1857

VENEZUELA

Libreria del Este,

Avda F. Miranda 52, Aptdo. 60337,

Edificio Galipan, Caracas 106 Tel. 32.23.01/33.26.04/33.24.73

YUGOSLAVIA

Jugoslovenska Knjiga, Terazije 27,

P.O.B. 36, Beograd.

Tel. 621.992

Orders and inquiries from countries where Sales Agents have not yet been appointed should be sent to OECD Publications Office, 2 rue AndréPascal, F 75775 Paris Cedex 16. 


\section{Organisation for Economic Co-operation and Development}

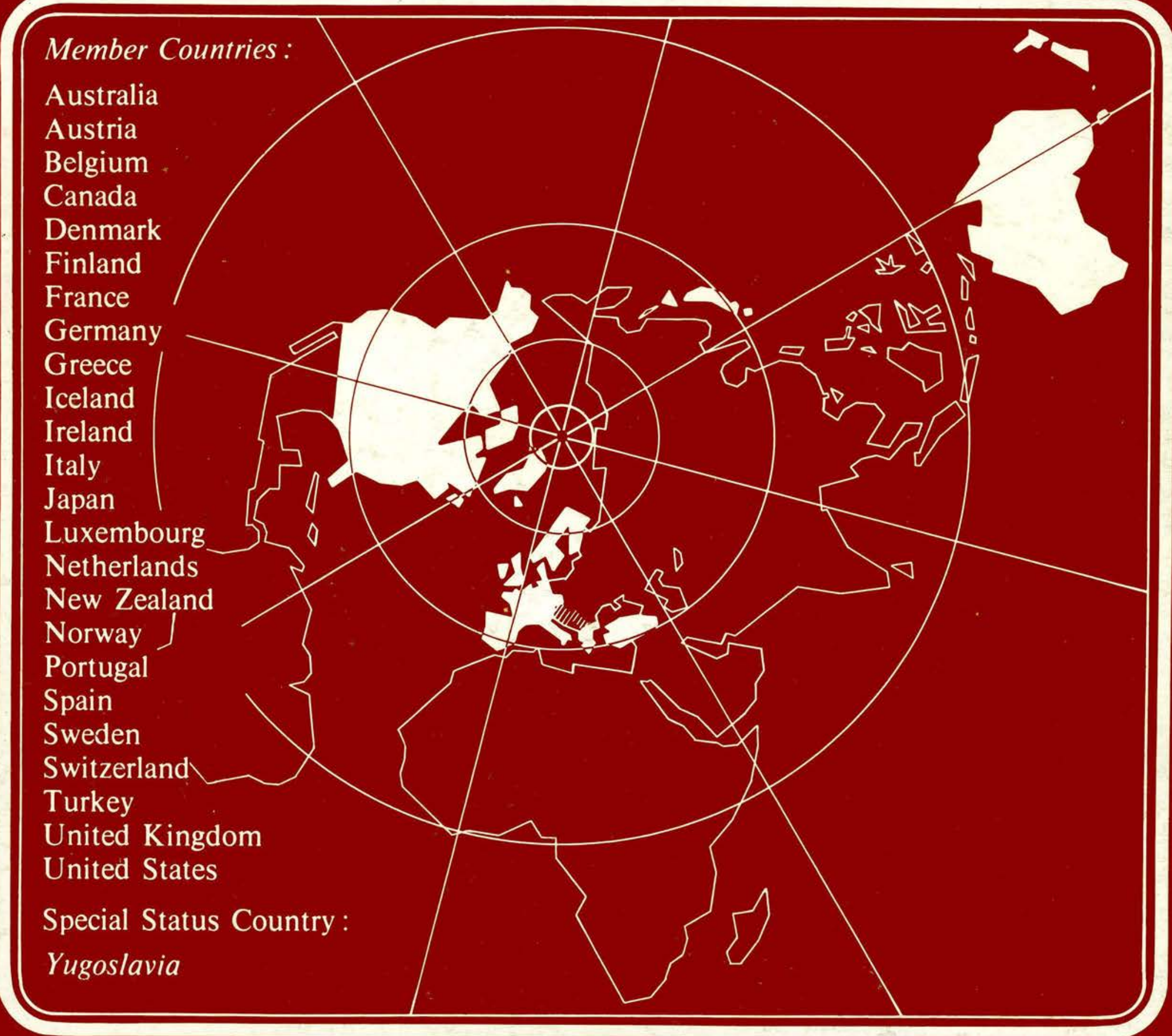

